\title{
Isoprene oxidation by nitrate radical: alkyl nitrate and secondary organic aerosol yields
}

\author{
A. W. Rollins ${ }^{1}$, A. Kiendler-Scharr ${ }^{3}$, J. L. Fry ${ }^{1, *}$, T. Brauers ${ }^{3}$, S. S. Brown ${ }^{4}$, H.-P. Dorn ${ }^{3}$, W. P. Dubé ${ }^{4}$, H. Fuchs ${ }^{4}$, \\ A. Mensah ${ }^{3}$, T. F. Mentel $^{3}$, F. Rohrer ${ }^{3}$, R. Tillmann ${ }^{3}$, R. Wegener ${ }^{3}$, P. J. Wooldridge ${ }^{1}$, and R. C. Cohen ${ }^{1,2}$ \\ ${ }^{1}$ Department of Chemistry; University of California Berkeley, Berkeley, CA, USA \\ ${ }^{2}$ Department of Earth and Planetary Science, University of California Berkeley, Berkeley, CA, USA \\ ${ }^{3}$ Institute of Chemistry and Dynamic of the Geosphere, Forschungszentrum Jülich, Germany \\ ${ }^{4}$ Chemical Sciences Division, NOAA Earth System Research Laboratory, Boulder, CO, USA \\ *now at: Department of Chemistry; Reed College, Portland, OR, USA
}

Received: 27 February 2009 - Published in Atmos. Chem. Phys. Discuss.: 3 April 2009

Revised: 13 July 2009 - Accepted: 31 August 2009 - Published: 15 September 2009

\begin{abstract}
Alkyl nitrates and secondary organic aerosol (SOA) produced during the oxidation of isoprene by nitrate radicals has been observed in the SAPHIR (Simulation of Atmospheric PHotochemistry In a large Reaction Chamber) chamber. A $16 \mathrm{~h}$ dark experiment was conducted with temperatures at 289-301 K, and maximum concentrations of $11 \mathrm{ppb}$ isoprene, 62.4 $\mathrm{ppb}_{3}$ and $31.1 \mathrm{ppb} \mathrm{NO}_{\mathrm{X}}$. We find the yield of nitrates is $70 \pm 8 \%$ from the isoprene $+\mathrm{NO}_{3}$ reaction, and the yield for secondary dinitrates produced in the reaction of primary isoprene nitrates with $\mathrm{NO}_{3}$ is $40 \pm 20 \%$. We find an effective rate constant for reaction of $\mathrm{NO}_{3}$ with the group of first generation oxidation products to be $7 \times 10^{-14}$ molecule ${ }^{-1} \mathrm{~cm}^{3} \mathrm{~s}^{-1}$. At the low total organic aerosol concentration in the chamber $\left(\max =0.52 \mu \mathrm{g} \mathrm{m}^{-3}\right)$ we observed a mass yield ( $\triangle \mathrm{SOA}$ mass $/ \Delta$ isoprene mass) of $2 \%$ for the entire $16 \mathrm{~h}$ experiment. However a comparison of the timing of the observed SOA production to a box model simulation of first and second generation oxidation products shows that the yield from the first generation products was $<0.7 \%$ while the further oxidation of the initial products leads to a yield of $14 \%$ (defined as $\Delta \mathrm{SOA} / \Delta$ isoprene $^{2 \mathrm{X}}$ where $\Delta$ isoprene $e^{2 \mathrm{X}}$ is the mass of isoprene which reacted twice with $\mathrm{NO}_{3}$ ). The SOA yield of $14 \%$ is consistent with equilibrium partitioning of highly functionalized $\mathrm{C}_{5}$ products of isoprene oxidation.
\end{abstract}

Correspondence to: R. C. Cohen (rccohen@berkeley.edu)

\section{Introduction}

Isoprene (2-methyl-1,3-butadiene) is globally the most abundant non-methane volatile organic compound (VOC), with an estimated emission of 440-660 Tg C/year (Guenther et al., 2006). Total non-methane VOC emissions are estimated at $1150 \mathrm{Tg} \mathrm{C} / \mathrm{year}$ biogenic (Guenther et al., 1995) and $186 \mathrm{Tg}$ C/year anthropogenic (Olivier et al., 2005) making isoprene the source of $34 \%-51 \%$ of the non-methane organic carbon emitted to Earth's atmosphere. The combined factors of its source strength and high reactivity to atmospheric oxidants $\left(\mathrm{OH}, \mathrm{O}_{3}\right.$, and $\left.\mathrm{NO}_{3}\right)$, make isoprene a major factor in the chemistry of the troposphere. As a result, tropospheric $\mathrm{O}_{3}$ and aerosol burdens and distributions are highly sensitive to the products of isoprene chemistry (e.g., Chameides et al., 1988; Thornton et al., 2002; Henze and Seinfeld, 2006; Wu et al., 2007). Recent field studies have provided mass spectroscopic evidence for the existence of isoprene oxidation products in ambient aerosol (Gómez-González et al., 2008; Surratt et al., 2008). The identified tracer molecules include tetrols and hydroxynitrates, which mostly appear to be produced by the oxidation of both double bonds in isoprene either through photooxidation $(\mathrm{OH})$ of isoprene or through mixed $\mathrm{NO}_{3} / \mathrm{OH}$ oxidation, and organosulfates which are believed to be produced by the subsequent reaction of tetrols or hydroxynitrates with acidic particles $\left(\mathrm{NH}_{4} \mathrm{HSO}_{4}\right)$.

Isoprene emissions are near zero at night when nitrate radical chemistry is typically thought to be of primary importance. However, isoprene emitted during the day is observed to persist after sundown when $\mathrm{NO}_{3}$ concentrations begin to increase (Starn et al., 1998; Stroud et al.;

Published by Copernicus Publications on behalf of the European Geosciences Union. 
Steinbacher et al., 2005), and theoretical arguments suggest that $\mathrm{NO}_{3}$ can be important in shaded forest canopies near $\mathrm{NO}_{\mathrm{X}}\left(\mathrm{NO}_{\mathrm{X}}=\mathrm{NO}=\mathrm{NO}_{2}\right)$ sources even during daytime (Fuentes et al., 2007). $\mathrm{NO}_{3}$ has been measured during the day in polluted urban areas (Geyer et al., 2003a) and new developments in $\mathrm{NO}_{3}$ instrumentation allowing for sub-ppt sensitivity are beginning to reveal the potential importance of $\mathrm{NO}_{3}-\mathrm{VOC}$ chemistry during the day (Brown et al., 2005). Global estimates made with GEOS-Chem suggest that $\approx 6 \%$ of the total isoprene oxidation occurs by $\mathrm{NO}_{3}(\mathrm{Ng}$ et al., 2008). Regionally however, in areas such as cities and power plants surrounded by forest where high $\mathrm{NO}_{\mathrm{X}}$ emissions are collocated with isoprene sources, $\mathrm{NO}_{3}$ has been shown to oxidize $22 \%$ or more of the total daily isoprene emission (Brown et al., 2009).

Alkyl nitrates $\left(\mathrm{RONO}_{2}\right)$ formed from reactions of isoprene with $\mathrm{NO}_{3}$ represent $\approx 50 \%$ of the total nitrate production in isoprene rich regions, with likely consequences for tropospheric $\mathrm{O}_{3}$ production (Horowitz et al., 1998; von Kuhlmann et al., 2004; Fiore et al., 2005; Horowitz et al., 2007; Wu et al., 2007). Photochemical oxidation of isoprene has been shown in chamber studies to produce aerosol with mass yields that are small (1-3\%) (Kroll et al., 2005, 2006) compared to yields from other biogenic VOC's, but due to the source strength of isoprene this could be the single most significant source of SOA on Earth (Henze and Seinfeld, 2006; Zhang et al., 2007; Ng et al., 2008). SOA from the reaction of isoprene with $\mathrm{NO}_{3}$ has been recently studied $(\mathrm{Ng}$ et al., 2008), with significant yields observed (4.3-23.8\% for $2.2-68.1 \mu \mathrm{g} / \mathrm{m}^{3}$ isoprene reacted). The nitrate radical reacts primarily with unsaturated VOC's and therefore is a particularly effective oxidant for many biogenic compounds. Isoprene which has two double bonds, can react with $\mathrm{NO}_{3}$ at each bond, and the products of both oxidation steps can affect both $\mathrm{NO}_{\mathrm{x}}$ and $\mathrm{NO}_{\mathrm{y}}\left(\mathrm{NO}_{\mathrm{y}}=\mathrm{NO}_{\mathrm{X}}+\right.$ organic nitrates $+\mathrm{NO}_{3}+\mathrm{N}_{2} \mathrm{O}_{5}+\mathrm{HNO}_{2}+\mathrm{HNO}_{3}+$ particulate nitrate) partitioning as well as SOA formation. There is little detailed information about the fate of the initial oxidation products, which are primarily alkenes and aldehydes. Both functional groups may have important roles in the reactivity of the initial products.

Kinetics of the first step in isoprene oxidation by $\mathrm{NO}_{3}$ are well established. The rate constant has been measured by a number of investigators using various methods (Atkinson et al., 1984; Benter and Schindler, 1988; Dlugokencky and Howard, 1989; Barnes et al., 1990; Berndt and Boge, 1997; Wille et al., 1991; Suh et al., 2001) and the recommended rate constant at $298 \mathrm{~K}$ is $6.8 \times 10^{-13}$ molecule ${ }^{-1} \mathrm{~cm}^{3} \mathrm{~s}^{-1}$ (Atkinson et al., 2008). The mechanism for the reaction is addition of $\mathrm{NO}_{3}$ to one of the double bonds, mainly at the $\mathrm{C}_{1}$ position. Theoretical and experimental studies are in good agreement that the main product of the reaction in the presence of oxygen will be a $\mathrm{C}_{5}$ nitrooxycarbonyl. Minor products include $\mathrm{C}_{5}$ hydroxynitrates, $\mathrm{C}_{5}$ nitrooxyhydroperoxides, methyl vinyl ketone (MVK) and methacrolein (MACR)
(Barnes et al., 1990; Skov et al., 1992; Ng et al., 2008). Ng et al. (2008) also identified many other gas and particle phase products from isoprene+NO $\mathrm{NO}_{3}$. $\mathrm{SOA}$ was observed to form from both first generation and second generation products. Reaction of the $\mathrm{C}_{5}$-hydroxynitrate with $\mathrm{NO}_{3}$ was more correlated with production of SOA than was the reaction of the other major $\mathrm{C}_{5}$ products. Highly functionalized $\mathrm{C}_{10}$ peroxides were also identified in the gas and particle phases. $\mathrm{Ng}$ et al. (2008) concluded that SOA in this system is produced more efficiently by $\mathrm{RO}_{2}+\mathrm{RO}_{2}$ reactions than by $\mathrm{RO}_{2}+\mathrm{NO}_{3}$ reactions.

In this work we report a chamber experiment on the reaction of isoprene $+\mathrm{NO}_{3}$ performed with isoprene (max $\left.11 \mathrm{ppb}\right)$ $\mathrm{O}_{3}(\max 62.4)$ and $\mathrm{NO}_{\mathrm{X}}(\max 31.1 \mathrm{ppb})$ where $\mathrm{NO}_{3}$ is generated in situ via the reaction of $\mathrm{O}_{3}+\mathrm{NO}_{2}$. To date, the isoprene $+\mathrm{NO}_{3}$ experiment with the lowest reported reactant concentrations is that of $\mathrm{Ng}$ et al. (2008) who used a lower limit of $18.4 \mathrm{ppb}$ isoprene and added $\mathrm{N}_{2} \mathrm{O}_{5}$ directly to the chamber. In this experiment high precision measurements of both gas phase and particle phase products have been made, including especially detailed observations of nitrogen oxides. $\mathrm{NO}, \mathrm{NO}_{2}, \mathrm{NO}_{3}, \mathrm{~N}_{2} \mathrm{O}_{5}$, and total alkyl nitrates $\left(\Sigma \mathrm{RONO}_{2}\right)$ were observed. This unique set of measurements provides a new measure of the alkyl nitrate yield and allows us to estimate the reactivity of the initial oxidation products, strengthening our understanding of the mechanism by which gas and aerosol products are produced in the ambient environment.

\section{Experimental}

The experiment was conducted in the SAPHIR chamber in Jülich, Germany. The reaction chamber is a double walled $120 \mu \mathrm{m}$ Teflon-FEP cylindrical bag, $5 \mathrm{~m}$ in diameter and $18 \mathrm{~m}$ long providing a volume of $\approx 270 \mathrm{~m}^{3}$. The chamber is housed in an aluminum structure with shutters that can be left open to outside lighting, or closed to simulate nighttime chemistry. For this experiment the shutters were always closed. During experiments the chamber is overpressured by 40-60 Pa with respect to the ambient pressure, and the space between the two FEP sheets is continually flushed with high purity $\mathrm{N}_{2}$. These measures isolate the air inside the chamber from outside air. Air sampled from the chamber during experiments is replaced with synthetic dry air to maintain the positive pressure. A mixing fan inside the chamber continuously stirs the gas in the chamber to maintain a spatially uniform mixture with a mixing time of $2-3 \mathrm{~min}$. SAPHIR has been described in further detail elsewhere (Bossmeyer et al., 2006; Rohrer et al., 2005; Wegener et al., 2007).

\subsection{Instrumentation}

This experiment was conducted on 18 July 2007 during an intercomparison campaign focused on measurements of $\mathrm{NO}_{3}$ (Dorn et al., 2009) and $\mathrm{N}_{2} \mathrm{O}_{5}$ (Apodaca et al., 2009), 
during which ten different instruments for measurement of $\mathrm{NO}_{3}$ and/or $\mathrm{N}_{2} \mathrm{O}_{5}$ were co-located at the SAPHIR chamber. $\mathrm{NO}_{3}$ and $\mathrm{N}_{2} \mathrm{O}_{5}$ measurements were found to be in agreement to $\pm 10 \%$ for almost all of the instruments throughout the campaign. Figures and analysis in this paper make use of Cavity Ringdown Spectroscopy (CaRDS) measurements reported by Brown and coworkers (Brown et al., 2001; Dubé et al., 2006) with accuracies of $+12 \% /-9 \%$ for $\mathrm{NO}_{3}$ and $+11 \% /-8 \%$ for $\mathrm{N}_{2} \mathrm{O}_{5}$ (Fuchs et al., 2008). Measurements of isoprene were obtained by Proton Transfer Reaction - Mass Spectrometry (PTR-MS), and Gas Chromatography with Flame Ionization Detector (GC-FID). Volatile organic compounds (VOC) including MVK, MACR and methyl ethyl ketone (MEK) were also measured with GC-FID. NO and $\mathrm{NO}_{2}$ were measured with a Chemiluminescence (CL) instrument equipped with a photolytic converter (ECO Physics CLD TR 780). $\mathrm{NO}_{2}$ as well as the higher nitrogen oxide classes total peroxy nitrates ( $\Sigma \mathrm{PNs})$, total alkyl and multifunctional nitrates $\left(\Sigma \mathrm{RONO}_{2}\right)$ were also measured by Thermal Dissociation - Laser Induced Fluorescence (TD-LIF) (Thornton et al., 2000; Day et al., 2002). The TD-LIF $\Sigma \mathrm{RONO}_{2}$ measurement includes alkyl nitrates only, not peroxy nitrates or $\mathrm{HNO}_{3}$. Ozone was measured with a UV Photometer (ANSYCO O341M), as well as with a CL detector (ECO Physics CLD AL 700) modified as described by Ridley et al. (1992). Both $\mathrm{O}_{3}$ instruments were in good agreement and figures in this paper show the CL measurements. Aerosol size distribution, surface area, volume, and total number density were obtained with a Scanning Mobility Particle Sizer (SMPS) (TSI model 3936L85) and Condensation Particle Counter (CPC, TSI model 3785) with time resolutions of $7 \mathrm{~min}$ and $20 \mathrm{~s}$ respectively. A high resolution $(\Delta m / m=250 \mathrm{ppm}$ at $m / z=100$, (DeCarlo et al., 2006)) aerosol mass spectrometer (Aerodyne HR-ToF-AMS) was operated to measure the chemical composition of the nonrefractory aerosol, providing data every $2 \mathrm{~min}$. The AMS was connected to the SAPHIR chamber via a stainless steel tube designed to minimize losses in the sampling line. Details of the AMS are described in (Canagartna et al., 2007). The high resolution (HR) capabilities of the AMS can distinguish between chemically different fragments at the same nominal mass (i.e. $\mathrm{NO}^{+}$and $\mathrm{CH}_{2} \mathrm{O}^{+}$at $m / z=30$ ) when signal to noise is high enough. In this manuscript we use the AMS to quantify aerosol organic nitrate content, following Fry et al. (2009). The AMS measures nitrate at $m / z 30$ $\left(\mathrm{NO}^{+}\right)$and $m / z 46\left(\mathrm{NO}_{2}^{+}\right) . \mathrm{NH}_{4} \mathrm{NO}_{3}$ is characterized by a ratio of $\mathrm{NO}_{2}^{+} / \mathrm{NO}^{+}$of 0.35 with the instrument employed in this study, and is consistent with the reported ranges of this value of $0.33-0.56$ which have been observed using the Aerodyne AMS (Alfarra et al., 2006; Cottrell et al., 2008). In this experiment we found a much lower ratio of 0.156 which is taken as indication of organic nitrate. For the reported AMS nitrate, HR analysis was used to exclude the non nitrogen containing fragments from the nominally nitrate peaks at $m / z=30$ and 46 , as well as to ensure the other major peaks normally considered organic did not contain nitrogen. The signal at $m / z 30$ was observed to contain $\mathrm{NO}^{+}$and $\mathrm{CH}_{2} \mathrm{O}^{+}$. No significant contribution of organic ions was observed at $m / z$ 46. The measured SMPS mode diameter grew from initial $50 \mathrm{~nm}$ to $90 \mathrm{~nm}$ during the course of the experiment, and a transmission efficiency of 1 was assumed through the aerodynamic lens of the AMS. The collection efficiency, $\mathrm{CE}$, was assumed to be 0.5 for $\left(\mathrm{NH}_{4}\right)_{2} \mathrm{SO}_{4}$ and 1 for organics and nitrate. It is assumed at this point that the Relative Ionization Efficiency (RIE) for the nitrate is 1.1. Under these assumptions AMS and SMPS agree well when deriving a mass loading from SMPS size distributions with a density of 1.4 for Ammonium sulfate and 1.2 for the organic fraction.

\subsection{Experiment description}

The chamber was prepared by flushing for $12.5 \mathrm{~h}$ with clean synthetic air at a rate of $75 \mathrm{~m}^{3} / \mathrm{h}$. Starting at 06:20 UTC, the dark chamber was loaded with trace gasses to meet the intended experimental conditions (relative humidity $=57 \%$, ethane $5.5 \mathrm{ppb}$ as a tracer for dilution, $\mathrm{CO} 500 \mathrm{ppm}$ as an $\mathrm{OH}$ scavenger, isoprene $9.6 \mathrm{ppb}$, and $\mathrm{NO}_{2} 16 \mathrm{ppb}$, see Fig. 1). In addition we added ammonium sulfate seed aerosol $\left(3.5 \mu \mathrm{g} / \mathrm{m}^{3}\right)$. At $8: 50, \mathrm{O}_{3}(37 \mathrm{ppb})$ was added initiating the production of $\mathrm{NO}_{3}$. After $5 \mathrm{~h}$ of reaction time the chemistry was accelerated by injecting an additional 23 ppb $\mathrm{NO}_{2}$ and $43 \mathrm{ppb} \mathrm{O}_{3}$, and then approximately $1 \mathrm{~h}$ after the isoprene was fully consumed another $11 \mathrm{ppb}$ of isoprene was added. The slow reaction of $\mathrm{O}_{3}$ and $\mathrm{NO}_{2}$ generated $\mathrm{NO}_{3}$ radicals throughout the experiment, consuming the majority of the isoprene. Using a chemical kinetics box model we calculate that throughout the experiment $\approx 90 \%$ of the isoprene reacted with $\mathrm{NO}_{3}$ and $\approx 10 \%$ with $\mathrm{O}_{3}$. The GC-FID measurements of ethane were fitted to an exponential decay with a rate constant of $k_{\mathrm{dil}}=1.39 \times 10^{-5} \mathrm{~s}^{-1}$, which was applied to all species in the box model to account for dilution.

\subsection{Modeling}

The Kinetic PreProcessor (KPP V2.1) (Sandu and Sander, 2006) was used to produce code for kinetic box model simulations of the chamber experiment. Two sets of simulations were run. In one set KPP input was provided by the Master Chemical Mechamism (MCM V3.1) (Saunders et al., 2003). In another set of simulations the $\mathrm{MCM}$ isoprene $+\mathrm{NO}_{3}$ degradation scheme was modified and optimized to reproduce the chamber observations, leaving the isoprene $+\mathrm{O}_{3}$ scheme identical to that in the MCM. The full reaction set used in this second scheme is listed in Table 1, and both mechanisms are shown schematically in Fig. 2 for comparison. This second mechanism includes two main deviations from the MCM: Firstly, the yield to form alkyl nitrates as the first generation oxidation products of isoprene $+\mathrm{NO}_{3}$ is less than $100 \%$, and secondly, these initial oxidation products 

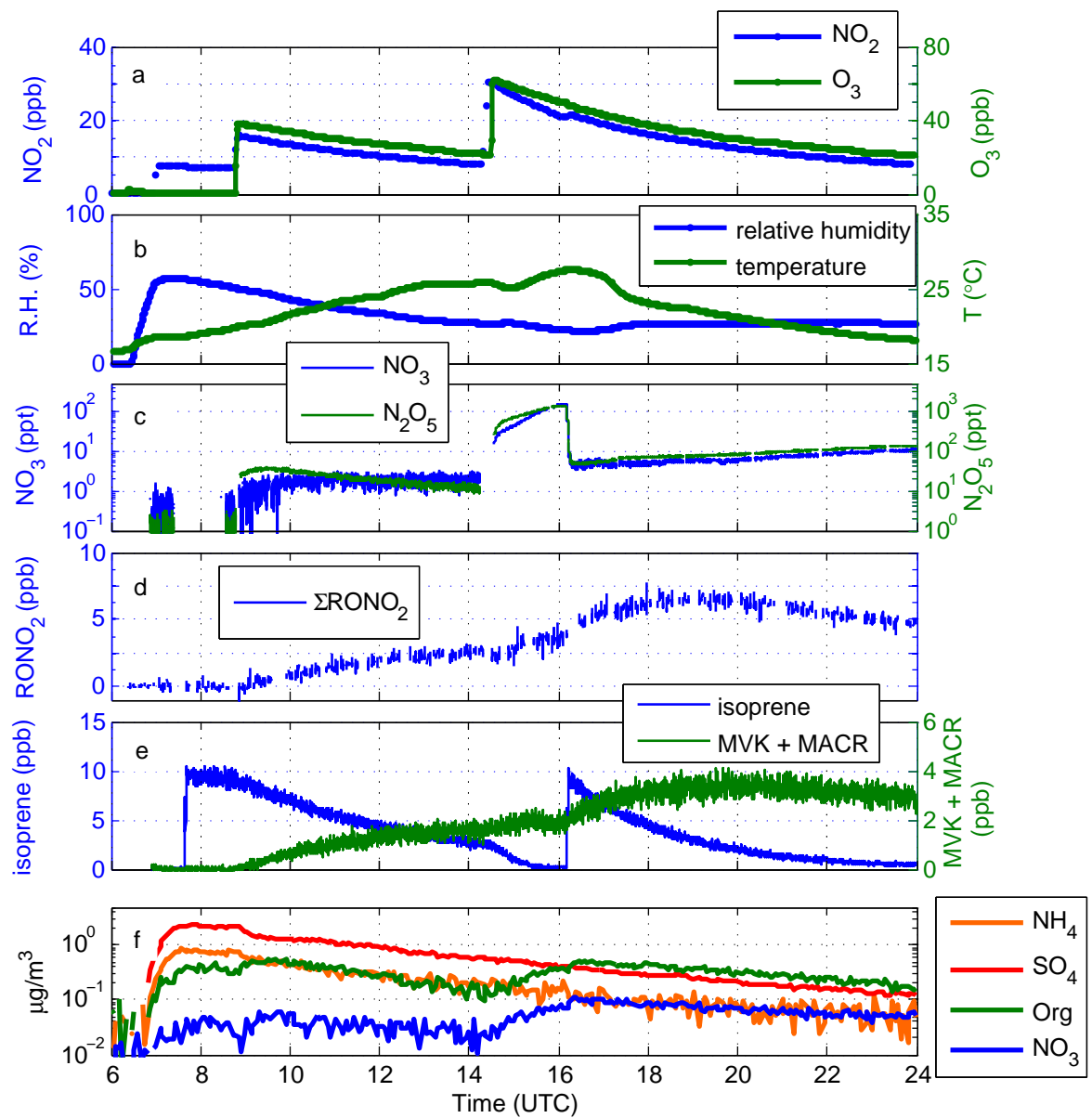

Fig. 1. Descending top to bottom, measurements of (a) $\mathrm{NO}_{2}$ and $\mathrm{O}_{3}$ (CL measurement), (b) chamber temperature and relative humidity (RH), (c) $\mathrm{NO}_{3}$ and $\mathrm{N}_{2} \mathrm{O}_{5}$ (CaRDS), (d) organic nitrates $(\mathrm{RONO} 2$, TD-LIF), (e) isoprene and the sum of methacrolein and methyl vinyl ketone (PTR-MS), and (f) AMS measurements of aerosol composition.

retain a double bond to which $\mathrm{NO}_{3}$ can add electrophilically, eventually forming additional multifunctional nitrates. Both sets of simulations used the same rate constants for chamber wall loss of $\mathrm{NO}_{3}, \mathrm{~N}_{2} \mathrm{O}_{5}$ and $\Sigma \mathrm{RONO} 2 . \mathrm{NO}_{3}$ and $\mathrm{N}_{2} \mathrm{O}_{5}$ loss rates were determined to be $1.0 \times 10^{-3} \mathrm{~s}^{-1}$ and $1.1 \times 10^{-4} \mathrm{~s}^{-1}$ from a VOC/particle free experiment. The loss rate of $\Sigma \mathrm{RONO}_{2}$ is determined to be $2.2 \times 10^{-5} \mathrm{~s}^{-1}$ by a best fit of the $\Sigma \mathrm{RONO}_{2}$ data and model at the end of the experiment when changes in $\Sigma \mathrm{RONO}_{2}$ are mostly due to dilution and wall loss.

Details of the chemistry included in the modified model are as follows:

- Inorganic Chemistry: The inorganic reactions and rates are taken directly from the MCM website ${ }^{1}$

- VOC Chemistry: MVK and MACR are assumed to be produced with yields of $3.5 \%$ each from iso-

\footnotetext{
${ }^{1} \mathrm{http}: / / \mathrm{mcm}$.leeds.ac.uk/MCM/.
}

prene $+\mathrm{NO}_{3}$, as was previously reported (Kwok et al., 1996) and these yields are held fixed in the simulations. $\mathrm{HO}_{\mathrm{X}}\left(\right.$ as $\mathrm{HO}_{2}$ ) is assumed to be produced by $80 \%$ of the $\mathrm{RO}_{2}$ reactions, which is a rough approximation consistent with the semi-explicit model used by Horowitz et al. (2007).

The only measurement we made of the other carbon products of isoprene oxidation is the $\mathrm{\Sigma RONO}_{2}$. We reduce the model complexity by only distinguishing these oxidation products by their $-\mathrm{ONO}_{2}$ content and whether they have undergone a second oxidizing reaction with $\mathrm{NO}_{3}$ or $\mathrm{O}_{3}$. NIT1 (Table 1, Fig. 2) is representative of all first generation oxidation products which have one $-\mathrm{ONO}_{2}$ group. The branching ratio to form NIT1 is a tunable parameter in the model. The group of species represented by NIT1 is reactive towards $\mathrm{NO}_{3}$ and $\mathrm{O}_{3}$. The effective rate for reaction of $\mathrm{NO}_{3}$ with this group of unsaturated species is also tunable, and is fit to be $7.0 \times 10^{-14}$ molecules ${ }^{-1} \mathrm{~cm}^{3} \mathrm{~s}^{-1}$ to achieve 


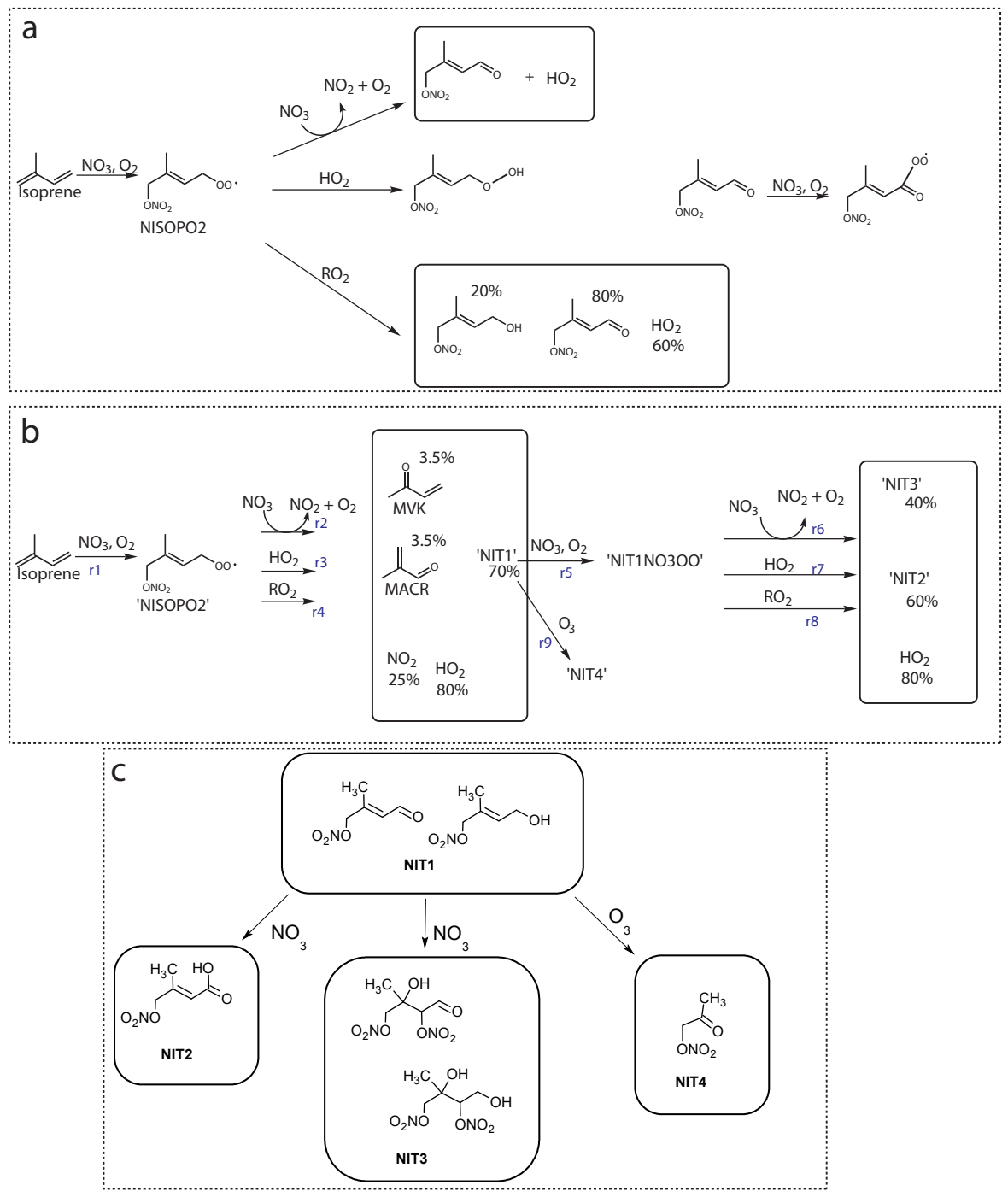

Fig. 2. (a) Schematic of isoprene $+\mathrm{NO}_{3}$ mechanism MCM V3.1. $100 \%$ of first generation oxidation products are alkyl nitrates. The only first generation product which is reactive towards $\mathrm{NO}_{3}$ is the carbonyl nitrate, which reacts in an aldehyde $+\mathrm{NO}_{3}$ mechanism at a rate of $1.1 \times 10^{-14}$ molecule ${ }^{-1} \mathrm{~cm}^{3} \mathrm{~s}-1$. (b) The modified mechanism used in this study. NIT1 -4 are lumped species representing organic nitrates produced by the first (NIT1) and second (NIT2, NIT3, NIT4) oxidation steps. NIT1 has one $\mathrm{RONO}_{2}$ group and one carbon-carbon double bond. Oxidation of the second double bond by $\mathrm{NO}_{3}$ is presumed to either leave the original nitrate functionality (NIT2) or add an additional $\mathrm{RONO}_{2}$ group (NIT3). Oxidation of NIT1 by $\mathrm{O}_{3}$ is presumed to leave the nitrate functionality (NIT4). NIT1NO3OO is the peroxy radical generated by reaction of NIT1 with $\mathrm{NO}_{3}$ followed by $\mathrm{O}_{2}$. (c) Some example likely structures of the lumped species NIT1 -4 used in the modified mechanism.

the best agreement between modeled and measured $\mathrm{NO}_{3}$ and $\mathrm{N}_{2} \mathrm{O}_{5}$ (see Sect. 3.1). The nitrate radical which reacts with NIT1 is presumed to lead to the production of additional $-\mathrm{ONO}_{2}$ functionality (NIT3, either di-nitrate or 2 organic nitrate molecules), or be converted to $\mathrm{NO}_{2}$ or $\mathrm{HNO}_{3}$ leaving the original $-\mathrm{ONO}_{2}$ group attached to a different carbon backbone (NIT2). The branching ratio between formation of NIT2 and NIT3 is the final tunable parameter in the model. The reaction of NIT1 with $\mathrm{O}_{3}$ makes NIT4 which is also treated as an unspecified $\mathrm{RONO}_{2}$. Example structures of NIT1-4 are shown in Fig. 2c. The lumped species NIT1-4 include, but are not limited to the molecules shown in the figure. The modeled $\Sigma \mathrm{RONO}_{2}$ is therefore $\mathrm{NIT} 1+\mathrm{NIT} 2+2 \times \mathrm{NIT} 3+\mathrm{NIT} 4+\mathrm{NISOPO} 2+\mathrm{NIT} 1 \mathrm{NO} 3 \mathrm{OO}$.

Because the primary oxidation product of isoprene $+\mathrm{NO}_{3}$ is believed to be 4-nitrooxy-3-methyl-2butanal, we use the reaction rates of the structurally similar 2-methyl-2-butene as a reference for the ratio 
Table 1. Gas phase reactions and rates included in reduced isoprene chemistry model.

\begin{tabular}{|c|c|c|c|}
\hline rxn \# & reaction & $\begin{array}{l}\text { rate at } 298 \mathrm{~K} \\
\text { (molecule }{ }^{-1} \mathrm{~cm}^{3} \mathrm{~s}^{-1} \\
\text { unless noted) }\end{array}$ & reference for rate coefficient \\
\hline 1 & $\mathrm{C} 5 \mathrm{H} 8+\mathrm{NO}_{3} \rightarrow \mathrm{NISOPO} 2$ & $6.78 \times 10^{-13}$ & MCM V3.1 \\
\hline 2 & $\mathrm{NISOPO} 2+\mathrm{NO}_{3} \rightarrow 0.70 \mathrm{NIT} 1+0.035 \mathrm{MVK}+0.035 \mathrm{MACR}$ & & \\
\hline & $+1.25 \mathrm{NO}_{2}+0.80 \mathrm{HO}_{2}$ & $2.5 \times 10^{-12}$ & MCM V3.1 \\
\hline 3 & $\begin{array}{l}\text { NISOPO2 }+\mathrm{HO}_{2} \rightarrow 0.70 \mathrm{NIT} 1+0.035 \mathrm{MVK}+0.035 \mathrm{MACR} \\
+0.25 \mathrm{NO}_{2}+0.80 \mathrm{HO}_{2}\end{array}$ & $2.3 \times 10^{-11}$ & MCM V3.1 \\
\hline 4 & $\begin{array}{l}\text { NISOPO } 2+\mathrm{RO}_{2} \rightarrow 0.70 \mathrm{NIT} 1+0.035 \mathrm{MVK}+0.035 \mathrm{MACR} \\
+0.25 \mathrm{NO}_{2}+0.80 \mathrm{HO}_{2}\end{array}$ & $1.30 \times 10^{-12}$ & MCM V3.1 \\
\hline 5 & $\mathrm{NIT} 1+\mathrm{NO}_{3} \rightarrow \mathrm{NIT} 1 \mathrm{NO} 3 \mathrm{OO}$ & $7 \times 10^{-14}$ & fit \\
\hline 6 & $\mathrm{NIT} 1 \mathrm{NO} 3 \mathrm{OO}+\mathrm{NO}_{3} \rightarrow 0.6 \mathrm{NIT} 2+0.4 \mathrm{NIT} 3+\mathrm{NO}_{2}+0.8 \mathrm{HO}_{2}$ & $2.5 \times 10^{-12}$ & MCM V3.1 \\
\hline 7 & $\mathrm{NIT} 1 \mathrm{NO} 3 \mathrm{OO}+\mathrm{HO}_{2} \rightarrow 0.6 \mathrm{NIT} 2+0.4 \mathrm{NIT} 3+0.8 \mathrm{HO}_{2}$ & $2.3 \times 10^{-11}$ & MCM V3.1 \\
\hline 8 & $\mathrm{NIT} 1 \mathrm{NO} 3 \mathrm{OO}+\mathrm{RO}_{2} \rightarrow 0.6 \mathrm{NIT} 2+0.4 \mathrm{NIT} 3+0.8 \mathrm{HO}_{2}$ & $1.30 \times 10^{-12}$ & MCM V3.1 \\
\hline 9 & $\mathrm{NIT} 1+\mathrm{O}_{3} \rightarrow \mathrm{NIT} 4$ & $3 \times 10^{-18}$ & fit (assumed $4.3 \times 10^{-5} \times \mathrm{k}_{5}$ ) \\
\hline 10 & $\mathrm{NO}_{3} \rightarrow$ walls & $1.0 \times 10^{-3} \mathrm{~s}^{-1}$ & fit \\
\hline 11 & $\mathrm{~N}_{2} \mathrm{O}_{5} \rightarrow$ walls & $1.1 \times 10^{-4} \mathrm{~s}^{-1}$ & fit \\
\hline 12 & $\mathrm{RONO}_{2} \rightarrow$ walls & $2.2 \times 10^{-5} \mathrm{~s}^{-1}$ & fit \\
\hline
\end{tabular}

of the reaction rates with $\mathrm{O}_{3}$ and $\mathrm{NO}_{3}$ (both rates taken from MCM). Thus, $k_{\mathrm{O}_{3}}=4.3 \times 10^{-5} \times k_{\mathrm{NO}_{3}}$. The choice to use 4-nitrooxy-3-methyl-2-butanal as the reference compound for these rates has a small impact on the outcome of the model because the $\mathrm{O}_{3}$ reaction is much slower than the $\mathrm{NO}_{3}$ reaction. The $\mathrm{O}_{3}$ Reaction (R9) accounts for $7 \%$ of the consumption of the NIT1 species throughout the entire model run, while during the short SOA growth period $(14: 30-16: 15)$ it is only $4 \%$. Using methacrolein as the reference compound increases these values to $26 \%$ and $17 \%$ respectively.

- Peroxy Radicals: Peroxy radicals in the model are generated by reactions of each double bond of isoprene with $\mathrm{NO}_{3}$. All peroxy radical $\left(\mathrm{RO}_{2}\right)$ reaction rates are taken directly from MCM. The initial isoprene nitrate peroxy radical $+\mathrm{RO}_{2}$ rate is $1.30 \times 10^{-12}$ molecule ${ }^{-1} \mathrm{~cm}^{3} \mathrm{~s}^{-1}$, and this rate is used also for all second generation $\mathrm{RO}_{2}+\mathrm{RO}_{2}$ reactions. All $\mathrm{RO}_{2}+\mathrm{NO}_{3}$ and $\mathrm{RO}_{2}+\mathrm{HO}_{2}$ reactions proceed at standard MCM rates of $2.5 \times 10^{-12}$ molecule ${ }^{-1} \mathrm{~cm}^{3} \mathrm{~s}^{-1}$ and $2.3 \times 10^{-11}$ molecule ${ }^{-1} \mathrm{~cm}^{3} \mathrm{~s}^{-1}$ respectively (see Table 1). The yield for product formation is modeled to be the same regardless of the peroxy radical reaction partner, and the products of all peroxy radical reactions are only distinguished by whether a stable alkyl nitrate or $\mathrm{NO}_{2}$ is formed. For example, two isoprene peroxy radicals could form a $\mathrm{C}_{10}$ peroxide, or two $\mathrm{C}_{5}$ products. These product channels are not tracked in the model because the only observable and therefore modeled quantities are $\mathrm{NO}_{\mathbf{X}}, \mathrm{NO}_{3}, \mathrm{~N}_{2} \mathrm{O}_{5}$ and $\Sigma \mathrm{RONO}_{2}$.

\section{Gas phase products}

We first describe the observations from the chamber and show that different time periods uniquely constrain some of the model parameters. Two distinct chemical environments dominated the chemistry in the chamber at three different time periods. These time periods are referred to by their UTC hour and are most obvious in the observations of $\mathrm{NO}_{3}$ and $\mathrm{N}_{2} \mathrm{O}_{5}$ (Fig. 1c). In what follows, the stated production rates of $\mathrm{NO}_{3}$, the fraction of isoprene reacted with $\mathrm{NO}_{3}$, and the peroxy radical fate are all calculated using the box model which is more extensively described in Sect. 2.3.

1. 08:00-14:30, Isoprene oxidation: During the initial phase the isoprene concentration was high and isoprene dominated the consumption of nitrate radicals. The $\mathrm{NO}_{3}$ production rate ranged from $0.56 \mathrm{ppt} \mathrm{s}^{-1}(2.0$ $\left.\mathrm{ppbhr}^{-1}\right)$ at $08: 00$ to $0.16 \mathrm{ppts}^{-1}\left(0.58 \mathrm{ppbhr}^{-1}\right)$ at 14:30. At any given time $>90 \%$ of the $\mathrm{NO}_{3}$ loss was due to reaction with isoprene, with the majority of the balance being to reaction with oxidation products. $\mathrm{Re}-$ action of peroxy radicals is predominately with other peroxy radicals and hydroperoxy radicals. $\mathrm{RO}_{2}+\mathrm{NO}_{3}$ accounts for $<5 \%$ of $\mathrm{RO}_{2}$ reactions.

2. 14:30-16:15, Secondary oxidation: During this second phase, the isoprene concentration decreased rapidly to zero and reaction with the initial oxidation products was a much more important sink for $\mathrm{NO}_{3}$. Between UTC $15: 18$ and 16:15 reaction with these initial oxidation products accounted for more than half of the total $\mathrm{NO}_{3}$ reactivity. Second generation oxidation products rapidly accumulated through the reaction of $\mathrm{NO}_{3}$ 
with the initial isoprene oxidation products. $\mathrm{RO}_{2}+\mathrm{NO}_{3}$ also accounted for a larger fraction of the peroxy radical reactions, peaking at $\approx 40-50 \%$ of total peroxy radical loss.

3. 16:15-24:00, Isoprene oxidation: During the third phase additional isoprene was added to the chamber, bringing the concentration to $11 \mathrm{ppb}$. Isoprene again was the dominant sink of $\mathrm{NO}_{3}$, suppressing both the production of the doubly oxidized products of isoprene and $\mathrm{RO}_{2}+\mathrm{NO}_{3}$ reactions.

\subsection{Optimized model parameters}

As previously discussed, three of the model parameters have been adjusted to minimize differences in the modelmeasurement comparison. These are: 1) Branching ratios for the formation of alkyl nitrates vs. $\mathrm{NO}_{2}$ from the isoprene $+\mathrm{NO}_{3}$ reaction, 2) reaction rate of first generation oxidation products with $\mathrm{NO}_{3}$, and 3 ) branching ratios for formation of alkyl nitrates and $\mathrm{NO}_{2}$ from the reaction of $\mathrm{NO}_{3}$ with the first generation oxidation products. Model optimization of the free parameters was achieved in the following order:

1. Branching ratio \#1: Stable nitrates result from addition of $\mathrm{NO}_{3}$ and $\mathrm{O}_{2}$ to isoprene followed by a radicalradical reaction that produces a closed shell product through either an abstraction reaction followed by a cleavage, or a recombination of the radicals (Fig. 2). The branching ratio $\left(Y_{A N 1}\right)$ to form alkyl nitrates from isoprene $+\mathrm{NO}_{3}$, is defined as the fraction of isoprene $+\mathrm{NO}_{3}$ reactions that eventually form stable nitrates:

$Y_{A N 1}=\frac{\Delta \Sigma \mathrm{RONO}_{2}}{\Delta \text { isoprene }}$

An initial attempt was made to evaluate this branching ratio directly from changes in the isoprene, $\mathrm{NO}_{3}, \mathrm{~N}_{2} \mathrm{O}_{5}$ and $\Sigma \mathrm{RONO}_{2}$ observations during second addition of isoprene to the chamber. This addition lead to a prompt consumption of a known amount of $\mathrm{NO}_{3}$ and $\mathrm{N}_{2} \mathrm{O}_{5}$, and subsequent production of alkyl nitrates and $\mathrm{NO}_{2}$. The measurements did not however resolve the isoprene consumed in this rapid reaction. This was because the time scales of chamber mixing and reaction were comparable such that the initial concentration of isoprene added was not measured precisely, resulting in no stepwise decrease observed in the isoprene concentration at 16:15 (see Fig. 1e). The branching ratio $Y_{A N 1}$ would be equal to $\Delta \Sigma \mathrm{RONO}_{2} / \Delta \mathrm{NO}_{3}$ if $\Delta \mathrm{NO}_{3}=\Delta$ isoprene, i.e. in the absence of another $\mathrm{NO}_{3}$ sink. However, because the $\mathrm{NO}_{3}$ concentration was high relative to $\mathrm{RO}_{2}$, we calculate that $\mathrm{RO}_{2}+\mathrm{NO}_{3} \rightarrow \mathrm{RO}+\mathrm{NO}_{2}+\mathrm{O}_{2}$ accounted for $\approx 15-25 \%$ of the total $\mathrm{RO}_{2}$ reactions, meaning that on the order of $20 \%$ of the sudden change in $\mathrm{NO}_{3}$ radicals was due to the reaction with peroxy radicals, not isoprene. Due to the uncertainty in the reaction rate for the specific peroxy radicals with $\mathrm{NO}_{3}$ it is not possible to precisely calculate the contribution of this reaction to the $\Delta \mathrm{NO}_{3}$. For the initial phase of the experiment however the concentration of $\mathrm{NO}_{3}$ was so low that the rate of $\mathrm{NO}_{3}+\mathrm{RO}_{2}$ is minor compared to $\mathrm{RO}_{2}+\mathrm{RO}_{2}$ and $\mathrm{RO}_{2}+\mathrm{HO}_{2}$, and uncertainties in the reaction rates other than $\mathrm{NO}_{3}$ +isoprene result in a small uncertainty in the branching ratio.

To evaluate the yields of alkyl nitrates and $\mathrm{NO}_{2}$ we therefore varied this yield in simulations run over the time period 07:00-13:00 UTC (Fig. 3). A yield of $70 \pm 8 \%$ alkyl nitrates and $30 \% \mathrm{NO}_{2}$ was found to minimize the accumulated residuals between model and measurements of $\Sigma \mathrm{RONO}_{2}$ and $\mathrm{NO}_{2}$ over this time period.

2. Alkyl nitrate $+\mathrm{NO}_{3}$ reaction rate: With the branching ratios for the first generation products fixed at $70 \%$ and $30 \%$ for alkyl nitrates and $\mathrm{NO}_{2}$ respectively, the time period 14:00-16:15 UTC was used to fit the rate coefficient for reaction of the lumped species $\mathrm{NIT} 1+\mathrm{NO}_{3}$. A rate coefficient of $7 \times 10^{-14} \pm 3 \times 10^{-14}$ molecules ${ }^{-1} \mathrm{~cm}^{3} \mathrm{~s}^{-1}$ was found to be optimal (Fig. 3) based on minimizing residuals in comparison of modeled and observed $\mathrm{NO}_{3}+\mathrm{N}_{2} \mathrm{O}_{5}$.

3. Alkyl nitrate $+\mathrm{NO}_{3}$ products: Using the optimized branching ratios for isoprene $+\mathrm{NO}_{3}$ and the optimized reaction rate, the branching ratio to form alkyl nitrates or $\mathrm{NO}_{2}$ from the second oxidation step was investigated. Focusing on the time period 14:00-16:15 UTC when the isoprene was depleted so that $\mathrm{RONO}_{2}+\mathrm{NO}_{3}$ was the primary sink of $\mathrm{NO}_{3}$, we examined the yield in $20 \%$ increments (Fig. 4). The model and measurements are in best agreement for a yield of $40 \% \pm 20 \%$. We note that a yield of greater than $0 \%$ for $\mathrm{NO}_{2}$ results in modeled $\mathrm{NO}_{2}$ which is significantly greater than the measurements. This implies that the second oxidation step has a high yield to form $\mathrm{HNO}_{3}$ directly.

Figure 5 shows a comparison between the MCM model, and the model optimized in this work for modeled $\Sigma \mathrm{RONO}_{2}$, $\mathrm{NO}_{2} \quad \mathrm{NO}_{3}$ and $\mathrm{N}_{2} \mathrm{O}_{5}$. Generally, the MCM overpredicts $\mathrm{NO}_{3}, \mathrm{~N}_{2} \mathrm{O}_{5}$ and alkyl nitrates, and underpredicts $\mathrm{NO}_{2}$.

Table 2 summarizes the results of studies in the literature that report quantifying the yield of total alkyl nitrates from the isoprene $+\mathrm{NO}_{3}$ reaction. Our observation of alkyl nitrate formation $(70 \pm 8 \%$ ) is equivalent to previously reported yields (65\%-80\%), within the combined experimental errors (Skov et al., 1992; Perring et al., 2009). The fact that multiple experiments conducted under different conditions (concentrations of isoprene and oxidants differing by more than a factor of 100) have all produced high yields of alkyl nitrates implies that the yield is robust and relatively insensitive to the 

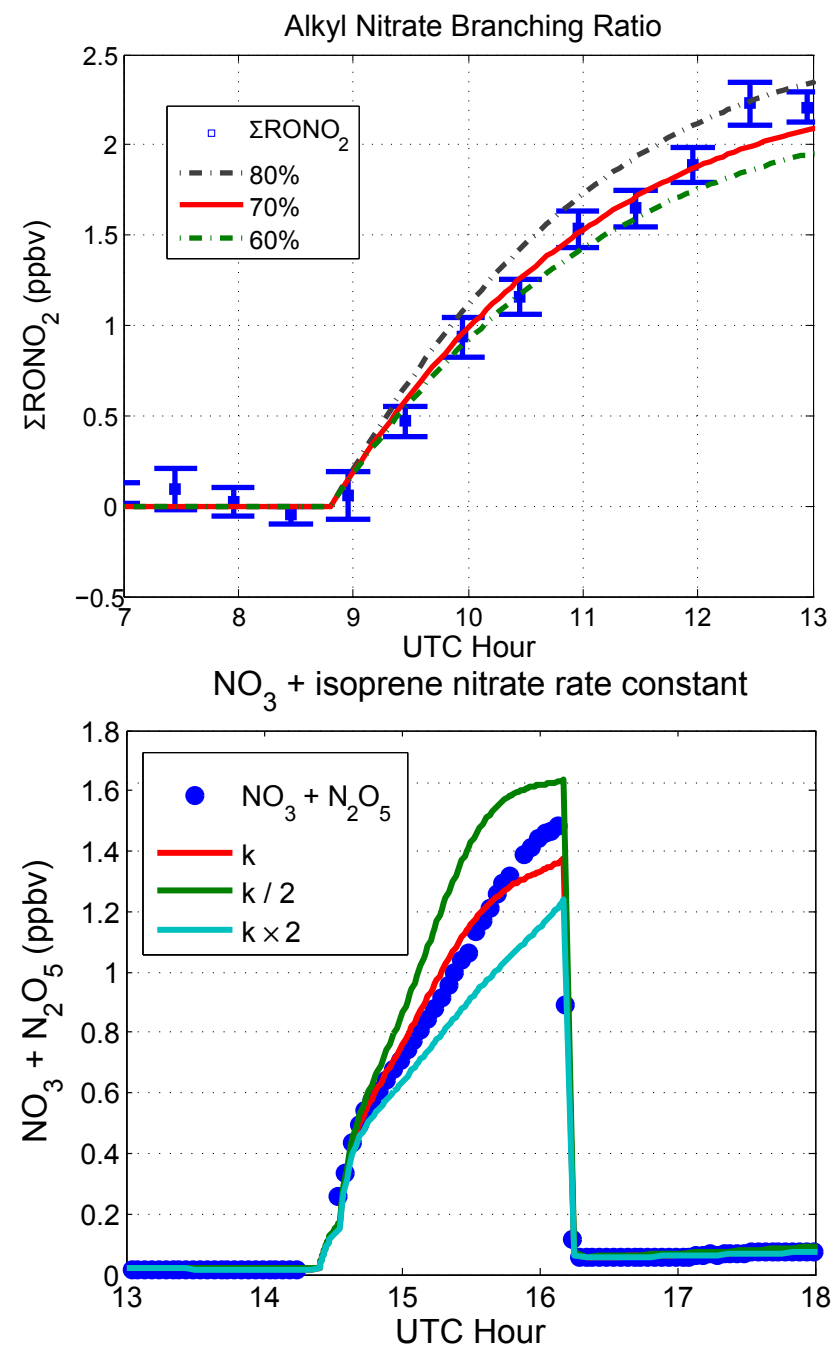

Fig. 3. Top: Model with varying branching ratios for production of alkyl nitrates from the initial isoprene $+\mathrm{NO}_{3}$ reaction. Error bars represent $\pm 2 \sigma$ of TD-LIF measurement. Bottom: NOAA $\mathrm{N}_{2} \mathrm{O}_{5}$ and model calculations using $k=7.0 \times 10^{-14}$ molecule ${ }^{-1} \mathrm{~cm}^{3} \mathrm{~s}-1$ for $\mathrm{NO}_{3}+\mathrm{NIT} 1$.

peroxy radical chemistry, and supports findings that the isoprene $+\mathrm{NO}_{3}$ reaction is possibly the single strongest source of alkyl nitrates in the atmosphere (Horowitz et al., 2007).

MACR, MVK and methyl ethyl ketone (MEK) were observed in small yields. Approximately $70 \%$ of the observed MVK and 80\% MACR were calculated to be from the reaction of isoprene with ozone, and the remainder is consistent with yields of $2-4 \%$ for both MVK and MACR from $\mathrm{NO}_{3}+$ isoprene. Production of $0.9 \mathrm{ppb}$ MEK was also observed by 24:00 UTC. The observations of the yields of MACR and MVK are consistent with previous observations. Barnes et al. (1990) reported an observable but small yield of MACR. Skov et al. (1992) report MACR below their FTIR detection limit $(<5 \%)$. Kwok et al. (1996) measured the production of MVK and MACR with GC-FID and reported

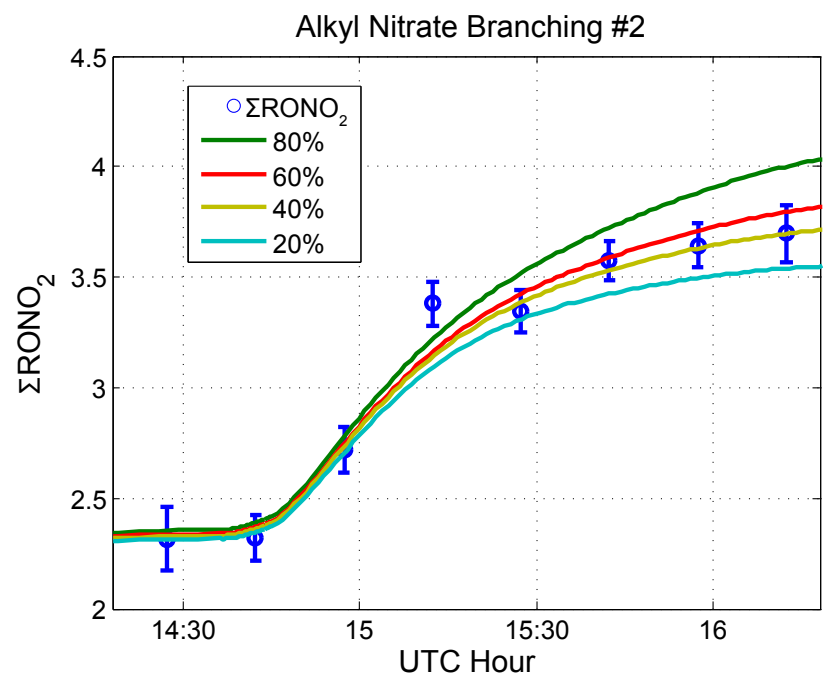

Fig. 4. Model runs varying the branching ratio to form alkyl nitrates from the oxidation of isoprene's second double bond.

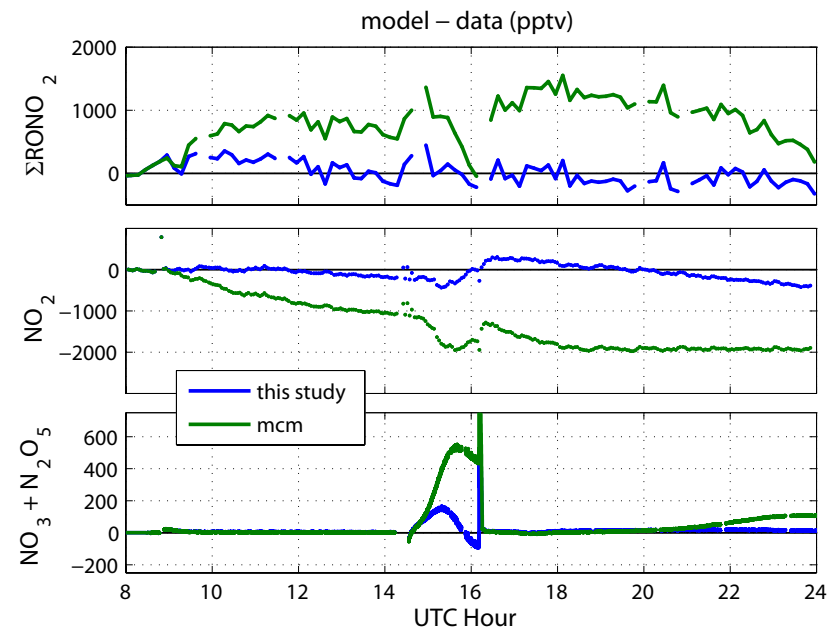

Fig. 5. Differences between data and model (data-model) for (top) $\Sigma \mathrm{RONO}_{2}$, (middle) $\mathrm{NO}_{2}$, and (bottom) $\mathrm{NO}_{3}+\mathrm{N}_{2} \mathrm{O}_{5}$. Green lines are calculations from MCM V3.1 and blue lines are the modified model from this work.

yields of 3.5\% for both MVK and MACR. Perring et al. (2009) observed a 7\% yield of the sum of MVK and MACR using PTR-MS. Skov et al. (1992) and Perring et al. (2009) measured product yields by adding isoprene to a chamber that was initially charged with ppm levels of $\mathrm{N}_{2} \mathrm{O}_{5}$. Kwok et al. (1996) added isoprene first as we did, but then injected $\mathrm{N}_{2} \mathrm{O}_{5}$ in ppm steps. All of these experiments would have resulted in a much larger $\mathrm{NO}_{3} / \mathrm{RO}_{2}$ ratio than in the experiment reported on here. These similar yet small yields of MVK and MACR observed in vastly different radical regimes are not surprising, supporting the conclusion that the yields of these 
products are primarily determined by the position at which $\mathrm{O}_{2}$ adds to the alkyl radical adduct generated by isoprene + $\mathrm{NO}_{3}$ as opposed to the peroxy radical reaction partner. The observation of $0.9 \mathrm{ppb}$ MEK at the end of the experiment is surprising. It seems that this product would have appeared in the FTIR detection scheme of Skov et al. (1992), however they do not report observing it. The mechanism responsible for the MEK in our experiments is unclear and might have been an interference from a different compound with the same GC retention time.

The rate constant that we find for the reaction of the first generation oxidation products with $\mathrm{NO}_{3}$ $\left(7 \times 10^{-14}\right.$ molecules $\left.{ }^{-1} \mathrm{~cm}^{3} \mathrm{~s}^{-1}\right)$ can be compared to known rate constants for compounds that are likely to be structurally similar. The observations that $40 \pm 20 \%$ of this reaction generates an alkyl nitrate, while $60 \pm 20 \%$ of the nitrogen does not reappear in any of our measurements indicates that the reaction occurred by $\approx 40 \%$ addition of $\mathrm{NO}_{3}$ to a double bond, and $\approx 60 \%$ abstraction of an aldehydic hydrogen to produce $\mathrm{HNO}_{3}$, with rate constants of $0.4 \times 7 \times 10^{-14}=2.8 \times 10^{-14}$ molecules $^{-1} \mathrm{~cm}^{3} \mathrm{~s}^{-1}$ and $0.6 \times 7 \times 10^{-14}=4.2 \times 10^{-14}$ molecules ${ }^{-1} \mathrm{~cm}^{3} \mathrm{~s}^{-1}$ for these two respective reactions. Both of these reaction channels are reasonable considering that multiple studies have found the $\mathrm{C}_{5}$-hydroxycarbonyl to account for most of the initial product yield. Though a significant amount of $\mathrm{HNO}_{3}$ may have been produced from this reaction, the increase in particulate nitrate appears to be due to the organic nitrates, indicated by the low $\mathrm{NO}_{2}^{+} / \mathrm{NO}^{+}$ratio observed with the AMS.

We compare the addition reaction to the reaction of $\mathrm{NO}_{3}$ with 3-methyl-2-butene-1-ol (MBO), which is a unsaturated alcohol structurally similar to the $\mathrm{C}_{5}$ nitrates produced by isoprene $+\mathrm{NO}_{3}$. The reaction rate constant for $\mathrm{MBO}$ has been measured as $1 \times 10^{-12}$ molecules ${ }^{-1} \mathrm{~cm}^{3} \mathrm{~s}^{-1}$ (Noda et al., 2002). While the effect of nitrate substitutions has not been studied on the reactions of alkenes with $\mathrm{NO}_{3}$, the electronegative nitrate group should be expected to slow the reaction. For example, in the case of the electrophilic $\mathrm{OH}$ addition to a double bond, the $\mathrm{C}_{5}$-hydroxynitrate reaction rate constant would be predicted to be a factor of 5 slower than that for MBO (Kwok and Atkinson, 1995). Scaling the MBO reaction by a factor of 5 yields a rate constant of $2 \times 10^{-13}$ molecules ${ }^{-1} \mathrm{~cm}^{3} \mathrm{~s}^{-1}$, ten times faster than our fitted value of $2.8 \times 10^{-14}$ molecules ${ }^{-1} \mathrm{~cm}^{3} \mathrm{~s}^{-1}$. The presumed rate constant for hydrogen abstraction of $4.2 \times 10^{-14}$ molecules ${ }^{-1} \mathrm{~cm}^{3} \mathrm{~s}^{-1}$ is on the fast end of the range that has been measured for aldehydes with $\mathrm{NO}_{3}$. D'Anna et al. (2001) measured a rate constant of $2.68 \times 10^{-14}$ molecules ${ }^{-1} \mathrm{~cm}^{3} \mathrm{~s}^{-1}$ for the reaction of 2methylbutanal, which differs from the $\mathrm{C}_{5}$ hydroxycarbonyl only by a nitrate substitution at the $\delta$ carbon. We caution that these comparisons are intended only to be rough, as we only are considering what are believed to be the highest yield isomers of the isoprene $+\mathrm{NO}_{3}$ reactions. Further, the measured
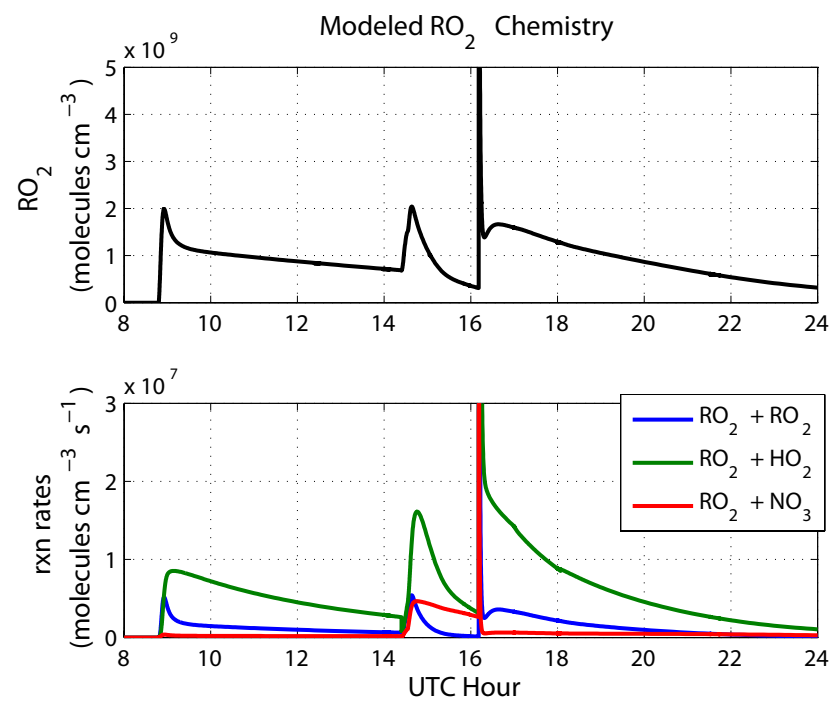

Fig. 6. Modeled calculations of (top) total peroxy radicals concentrations, and (bottom) sum of the rates of all $\mathrm{RO}_{2}+\mathrm{RO}_{2}$ reactions (blue), all $\mathrm{RO}_{2}+\mathrm{HO}_{2}$ reactions (green) and all $\mathrm{RO}_{2}+\mathrm{NO}_{3}$ reactions (red).

products from the initial reaction only account for $77 \%$ of the primary products $\left(\Sigma \mathrm{RONO}_{2}+\mathrm{MVK}+\mathrm{MACR}\right)$ and it may be reaction of one of the unresolved initial products that consumes most of this $\mathrm{NO}_{3}$ and produces SOA.

\subsection{Peroxy radical fate}

The relative concentration of peroxy radical reaction partners $\mathrm{RO}_{2}, \mathrm{HO}_{2}$ and $\mathrm{NO}_{3}$ can lead to differences in observed yields of i.e. peroxides, hydroperoxides and nitrates between experiments. We used the MCM based model described in this paper to calculate the relative importance of the three possible peroxy radical reaction partners, and the model includes $\mathrm{HO}_{2}$ enhancements due to the $\mathrm{OH}+\mathrm{CO} \rightarrow \mathrm{HO}_{2}$ reaction. Figure 6 shows the modeled contributions of these three radicals to the total $\mathrm{RO}_{2}$ reactions throughout the experiment. For the majority of the experiment the $\mathrm{RO}_{2}$ fate is almost entirely dominated by reaction with peroxy and hydroperoxy radicals. $\mathrm{NO}_{3}$ is modeled to be a significant reaction partner for peroxy radicals for a brief period of time in the middle of the experiment when the isoprene concentration was zero and the nitrate radical production rate was high $\left(\approx 1.5 \mathrm{ppt} \mathrm{s}^{-1}\right)$. During this time, a large concentration of $\mathrm{NO}_{3}$ accumulated $(\max \approx 150 \mathrm{ppt})$ at the same time that $\mathrm{RO}_{2}$ and $\mathrm{HO}_{2}$ production decreased.

While it would be interesting to use this experiment to help clarify the role of nighttime peroxy radical reactions in tropospheric chemistry, direct comparison of the modeled peroxy radical chemistry to the nighttime atmosphere is not conclusive. Box models simulating nighttime chemistry are in disagreement as to whether or when $\mathrm{NO}_{3}+\mathrm{RO}_{2}$ reactions can 
Table 2. Summary of studies reporting quantified yields of total organic nitrates from isoprene $+\mathrm{NO}_{3}$ reaction.

\begin{tabular}{|c|c|c|c|}
\hline description & detection & results & source \\
\hline $\begin{array}{l}\approx 10-24 \times 10^{13} \text { molecules } \\
\mathrm{cm}^{-3} \mathrm{~N}_{2} \mathrm{O}_{5} \text { added to } \\
\approx 5 \times 10^{14} \text { molecules } \mathrm{cm}^{-3} \\
\text { isoprene in a } 420 \mathrm{~L} \text { glass } \\
\text { reaction chamber at } 298 \pm 2 \mathrm{~K}\end{array}$ & In situ FT-IR of $\mathrm{RONO}_{2}$ & $\approx 80 \%$ yield of $\mathrm{RONO}_{2}$ & Skov et al. (1992) \\
\hline $\begin{array}{l}134 \mathrm{ppb} \text { isoprene added to } 82- \\
90 \mathrm{ppb} \mathrm{N}_{2} \mathrm{O}_{5} \text { in } 5500 \mathrm{~L} \text { teflon } \\
\text { chamber }\end{array}$ & $\begin{array}{l}\text { TD-LIF detection of } \Sigma \mathrm{RONO}_{2} \\
\text { and PTR-MS detection of spe- } \\
\text { cific oxidation products. }\end{array}$ & $65 \pm 10 \% \mathrm{RONO}_{2}$ yield & Perring et al. (2009) \\
\hline $\begin{array}{l}9.6 \mathrm{ppb} \text { isoprene, } 16 \mathrm{ppb} \mathrm{NO}_{2} \\
\text { and } 37 \mathrm{ppb} \mathrm{O} \mathrm{O}_{3} \text { added to } 270 \mathrm{~m}^{3} \\
\text { chamber }\end{array}$ & $\begin{array}{l}\text { TD-LIF detection of } \mathrm{RONO}_{2} \text {, } \\
\text { PTR-MS detection of isoprene. }\end{array}$ & $70 \pm 8 \%$ yield of $\mathrm{RONO}_{2}$ & This study \\
\hline
\end{tabular}

compete with $\mathrm{RO}_{2}+\mathrm{RO}_{2}$ and $\mathrm{RO}_{2}+\mathrm{HO}_{2}$ as a sink for $\mathrm{RO}_{2}$. At least two studies have concluded that in polluted environments $\mathrm{NO}_{3}$ can be an important sink for $\mathrm{RO}_{2}$ (Geyer et al., 2003b; Vaughan et al., 2006), while Bey et al. (2001) conclude that this process is insignificant. One of the reasons for this discrepancy may be the lack of detailed knowledge surrounding $\mathrm{RO}_{2}+\mathrm{RO}_{2}$ and $\mathrm{RO}_{2}+\mathrm{NO}_{3}$ reaction rates. Our experiment does not address constraints to these rates

We do note that model calculations (both the modified model and MCM) suggest that $\mathrm{HO}_{2}$ dominates the fate of peroxy radicals in the chamber. If all $\mathrm{RO}_{2}+\mathrm{HO}_{2}$ reactions formed a hydroperoxide via $\mathrm{RO}_{2}+\mathrm{HO}_{2} \rightarrow \mathrm{ROOH}$, than the majority of the oxidation products would be hydroperoxides instead of carbonyls. $\mathrm{Ng}$ et al. (2008) conducted a chamber study with higher total radical concentrations, but presumably similar ratios between $\mathrm{HO}_{2}$ and $\mathrm{RO}_{2}$. They observed a ratio of carbonylnitrate: nitrooxy hydroperoxide of $\approx 4$ 5. These combined results suggest that either the rate of $\mathrm{RO}_{2}+\mathrm{RO}_{2}$ is much faster relative to $\mathrm{RO}_{2}+\mathrm{HO}_{2}$ than used in our calculations, or that the yield for hydroperoxides from $\mathrm{RO}_{2}+\mathrm{HO}_{2}$ may be significantly less than $100 \%$. Laboratory (Hasson et al., 2004; Jenkin et al., 2007; Crowley and Dillon, 2008) and theoretical (Hasson et al., 2005) studies have shown that while the hydroperoxide yield from small peroxy radicals such as methyl peroxy and ethyl peroxy is near $100 \%$, larger more substituted peroxy radicals especially of the form $\mathrm{R}(\mathrm{O}) \mathrm{OO}$ may form alcohols or $\mathrm{OH}$ in high yields from the reaction with $\mathrm{HO}_{2}$. Photochemical box models have also been shown to more accurately reproduce field data if $\mathrm{RO}_{2}+\mathrm{HO}_{2}$ reactions are not chain terminating sinks of $\mathrm{HO}_{\mathrm{X}}$ (e.g., Thornton et al., 2002; Lelieveld et al., 2008). Thus, the yield of $\mathrm{ROOH}$ from $\mathrm{RO}_{2}+\mathrm{HO}_{2}$ reactions is currently an open question.

\section{Aerosol}

Figure 1 shows the raw AMS signal. The AMS indicated some brief initial increase in SOA with the injection of $\mathrm{O}_{3}$, but this production did not continue throughout the experiment and our analysis focuses on the more significant growth between 14:00 and 17:00 UTC. The number density of particles followed a monotonic exponential decay with a lifetime of $3.7 \mathrm{~h}$ throughout the experiment, presumably due to wall losses and chamber dilution. We assume that the observed OA at some time $t$ is due the combined effects of SOA production $P(t)$ and loss $L(t)$. The loss between AMS data points separated by $\Delta t$ is assumed to be proportional to the observed OA at some time $(C(t))$, such that losses alone would yield

$$
C(t+\Delta t)=C(t) e^{-\Delta t / 3.7 h}
$$

Therefore, the production between data points is the difference between the observed OA at time $t+\Delta t$ and the concentration that would have been observed from wall losses alone

$P(t)=C(t+\Delta t)-C(t) e^{-\Delta t / 3.7 h}$

To correct the AMS data for these losses we calculated the sum of the production terms for all previous time steps, so that the corrected OA is

$C_{\text {corrected }}(T)=C(0)+\sum_{t=0}^{T} P(t)$

In Fig. 7 we show the SOA corrected for this loss with $t=0$ being 7:23.

Secondary organic aerosol was observed to increase rapidly during the phase of the experiment when the isoprene concentration was low and the $\mathrm{NO}_{3}$ concentration was at its peak. In Fig. 1 panels a, c, and $\mathrm{f}$ it can be observed that the increases in organic and nitrate aerosol were correlated to 


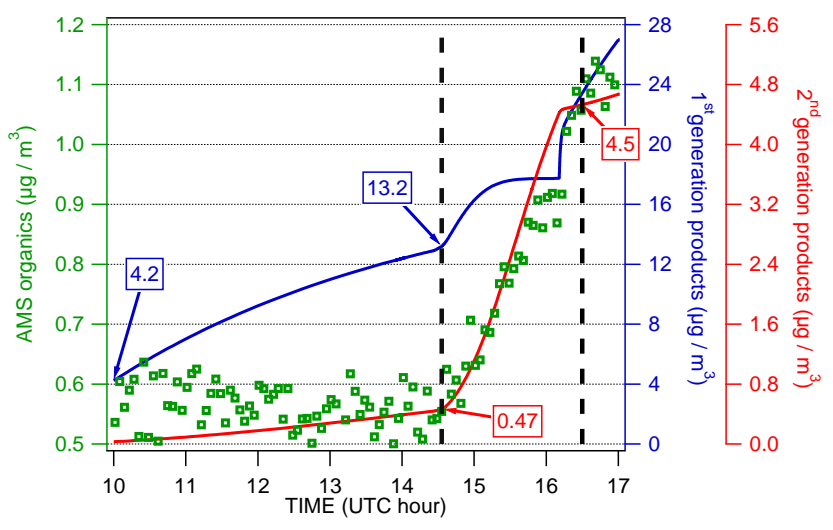

Fig. 7. Wall loss corrected AMS organics (green line, left axis), the modeled first generation oxidation products (blue line) and second generation oxidation products (red). Modeled first and second generation products are both expressed in units of $\mu \mathrm{g} / \mathrm{m}^{3}$ of the initial isoprene reacted, calculated as moles $/ \mathrm{m}^{3}$ of product $\times$ the molecular weight of isoprene, allowing the mass yield ( $\Delta \mathrm{VOC} / \Delta \mathrm{SOA})$ from each step to be calculated by comparing the product mass to measured organic aerosol mass. Different time periods used to calculate the yield of SOA from first generation oxidation (10:0014:30) and second generation oxidation (14:30-16:30) are separated by vertical dashed lines. The indicated data points are used for calculating the yields.

$\mathrm{NO}_{3}$ concentration, not $\mathrm{O}_{3}$. SOA production ceased immediately when the $\mathrm{NO}_{3}$ concentration decreased within minutes from $>150 \mathrm{ppt}$ to $<5 \mathrm{ppt}$, while $\mathrm{O}_{3}$ concentration was smoothly and slowly decreasing. The rapid growth of SOA observed uniquely in the presence of high $\mathrm{NO}_{3}$ concentration indicated that $\mathrm{SOA}$ formation was initiated by $\mathrm{NO}_{3}$ oxidation rather than $\mathrm{O}_{3}$. The fact that this growth also took place when isoprene concentration was at a minimum indicated that this SOA was generated upon reaction of $\mathrm{NO}_{3}$ with one of the initial isoprene oxidation products as opposed to isoprene itself. A final mass yield in the traditional sense

$Y=\frac{\Delta \text { organic aerosol mass }}{\Delta \text { isoprene mass }}$

of $2 \%$ was observed.

Figure 7 shows the change in AMS organic aerosol corrected for chamber dilution and wall loss (green), the modeled net amount of isoprene consumed by $\mathrm{NO}_{3}$ (blue), and the modeled net amount of isoprene nitrates (produced by the isoprene $+\mathrm{NO}_{3}$ reaction with a $70 \%$ yield) consumed by reaction with $\mathrm{NO}_{3}$ (extent of Reaction R5 from Table 1, red line). The blue curve shows $\Delta$ isoprene $\left(\mu \mathrm{g} / \mathrm{m}^{3}\right)$ and the red curve shows the moles of second generation oxidation products multiplied by the molecular weight of isoprene. We define this quantity as $\Delta$ isoprene $^{2 \mathrm{X}}$ because it is the mass concentration of isoprene which reacted two times with $\mathrm{NO}_{3}$.

Mass yields with respect to isoprene can be read for the first and second oxidation steps by comparing these lines

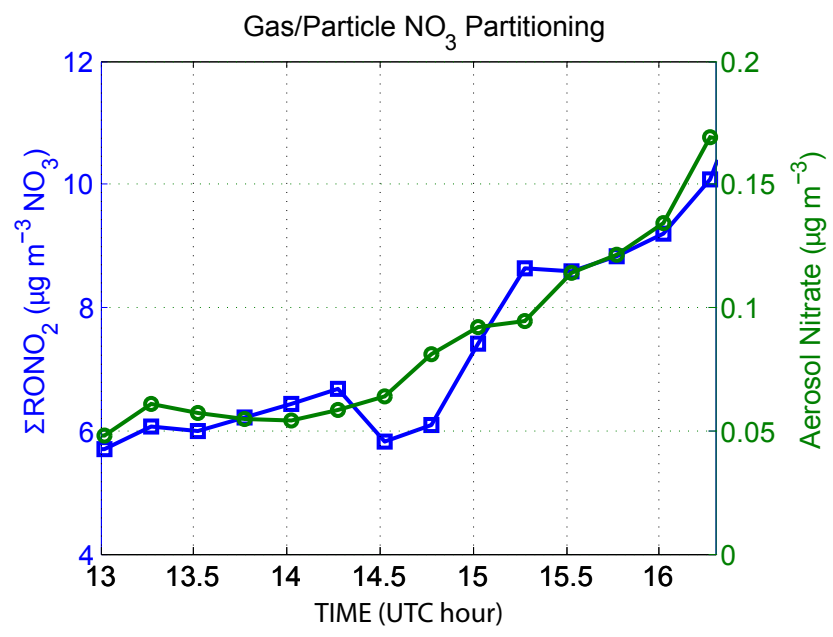

Fig. 8. Increases in TDLIF gas + aerosol $\mathrm{RONO}_{2}$ (blue) and AMS nitrate (green) during the second oxidation step in the chamber. AMS and TDLIF data are mapped to the same time resolution using 15 min means.

to the AMS data. We consider the time period between 10:00 UTC and 14:30 UTC as the isoprene oxidation period and use this time to calculate the SOA yield for isoprene. The period between 14:30 and 16:30 was when the secondary chemistry became much more important, and therefore we use this time period to calculate SOA from this secondary chemistry. In Fig. 7 these periods are distinguished with vertical dashed lines, and the calculated concentrations of the oxidation products are noted at these times. The change in isoprene consumed from 10:00-14:30 is $\Delta$ isoprene $=13.2-4.2=9 \mu \mathrm{g} \mathrm{m}^{-3}$, and from $14: 30-16: 30$ the change in $\Delta$ isoprene ${ }^{2 \mathrm{X}}=4.5-0.47=4.03 \mu \mathrm{g} \mathrm{m}^{-3}$. Using 15 min averages, we calculate that at 10:00, 14:30 and $16: 30$ the loss corrected OA concentrations were $0.56 \pm 0.04$, $0.56 \pm 0.04$, and $1.08 \pm 0.02 \mu \mathrm{g} \mathrm{m}^{-3}$ respectively. Therefore from 10:00-14:30 $\triangle \mathrm{OA}=0.00 \pm 0.06$ and from 14:30-16:30 $\triangle \mathrm{OA}=0.52 \pm 0.04$. Using the error in the $\triangle \mathrm{OA}$ from 10:00 14:30, we calculate the upper limit of SOA from isoprene by mass as $0.06 / 9=0.7 \%$. For the second oxidation step we calculate $0.5 / 4.03=14 \%$. The error however in the estimate of yield from second generation products is large and is dominated by the error in our fitting of the reaction rate for the first generation products with $\mathrm{NO}_{3}$, which we estimated at $43 \%$ of the reaction rate (Sect. 3.1) so that the SOA yield would be $14 \pm 6 \%$.

The TD-LIF instrumentation observes the sum of gas and aerosol organic nitrates. Figure 8 shows the changes in TDLIF signal and AMS nitrate, with both measurements averaged to $15 \mathrm{~min}$ resolution. We observed an increase of $\approx 4 \mu \mathrm{g} \mathrm{m}^{-3}$ total organic nitrate coincident with $0.12 \mu \mathrm{g} \mathrm{m}^{-3}$ aerosol nitrate. This indicates that $\approx 3 \%$ of the organic nitrate produced in the second oxidation step partitioned to 


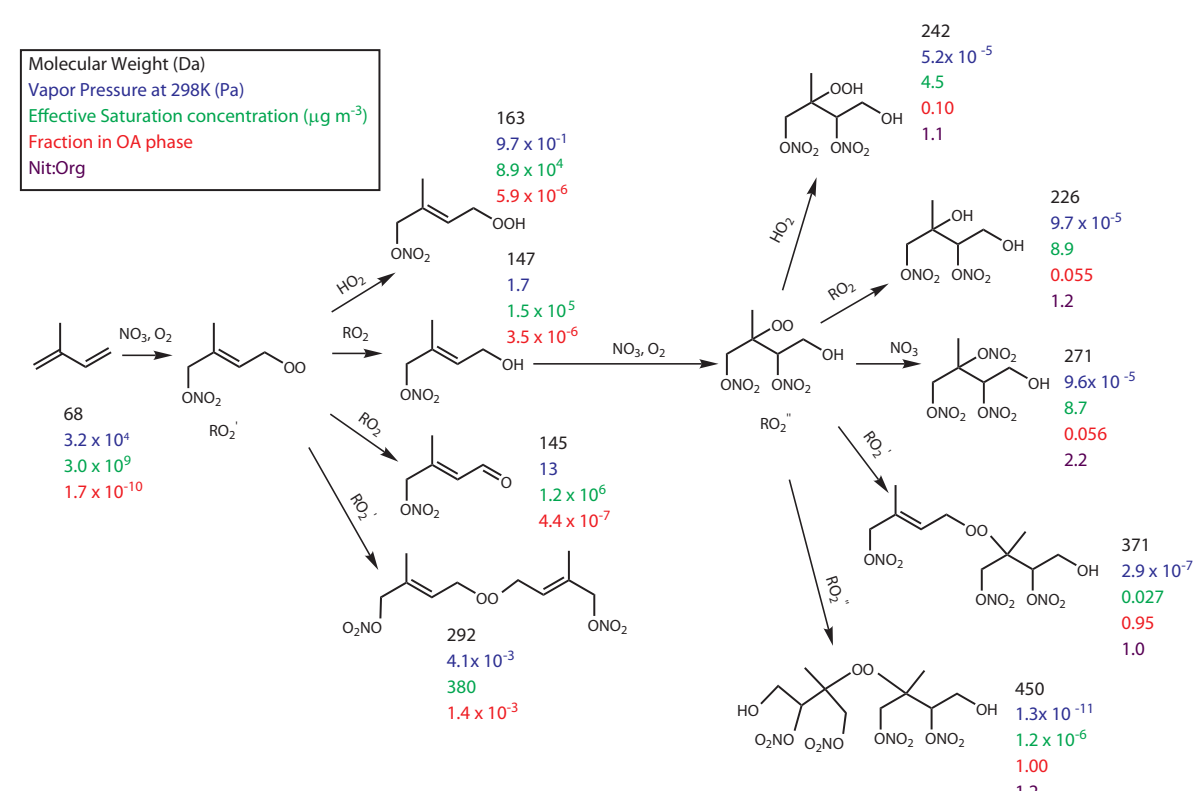

Fig. 9. The molecular weight ( $\mathrm{Da}$, black), vapor pressure (Pa, blue), effective saturation at $M W_{\mathrm{Om}}=226 \mathrm{~g} / \mathrm{mol}\left(\mu \mathrm{g} / \mathrm{m}^{3}\right.$, green $)$ equilibrium partitioning in OA phase at $0.52 \mu \mathrm{g} / \mathrm{m}^{3}$, and nitrate:organic ratio of the expected products of two stages of isoprene oxidation by $\mathrm{NO}_{3}$.

the particle phase. Of the final SOA products which exist in gas/particle equilibrium, the molecular yield can be calculated by scaling the mass yield $(14 \%)$ by the relative molecular weights of isoprene and of the SOA. For example, assuming particle/gas equilibrium if the primary SOA component were a $\mathrm{C}_{5}$-dinitrate-diol $\left(\mathrm{C}_{5} \mathrm{H}_{10} \mathrm{O}_{8} \mathrm{~N}_{2}\right)$ with $\mathrm{MW}=226$, the fraction of this molecule in the particle phase would be $14 \pm 6 \% \times 68 / 226=4 \pm 2 \%$ which is in agreement with our nitrate partitioning observation of $3 \%$.

\subsection{SOA composition}

The design of the gas phase model used in this study was primarily motivated by accurately calculating the partitioning of $\mathrm{NO}_{\mathrm{y}}$ throughout two stages of isoprene oxidation, and thus species were lumped according to their nitrate content. However, other studies (Barnes et al., 1990; Skov et al., 1992; Ng et al., 2008; Perring et al., 2009) have distinguished hydroxynitrates, carbonylnitrates, and peroxynitrates as the majority of the oxidation products. In Fig. 9 we consider physical properties including expected SOA yields of some of the specific molecules that may be responsible for SOA produced from the isoprene $+\mathrm{NO}_{3}$ system. These expected yields are then compared to the calculated $14 \pm 6 \%$ mass yield, and $4 \pm 2 \%$ molar yield from the second oxidation step.

This figure depicts the evolution of isoprene oxidation products through two stages of oxidation by nitrate radical, assuming that in each step the reaction takes place by addition of $\mathrm{NO}_{3}$ to one of the $\mathrm{C}=\mathrm{C}$ bonds. For simplicity, we consider secondary oxidation products produced by the reaction of $\mathrm{NO}_{3}$ with the $\mathrm{C}_{5}$ hydroxynitrate, as the consumption of this product was highly correlated with SOA formation in the study of $\mathrm{Ng}$ et al. (2008). We note that sulfate esters of i.e. the diol-dinitrate $(\mathrm{MW}=226)$ have been measured in particles both in labratory (Ng et al., 2008) and field (Surratt et al., 2008) samples, supporting these as likely candidates for SOA formation here. Similar second generation structures to those depicted could be arrived at from reactions of the $\mathrm{C}_{5}$ carbonylnitrate, and the predicted vapor pressures of these products are a factor of 6-8 higher than for the analogous hydroxynitrate. Although multiple isomers of each molecule are possible, we show only one of each for simplicity. Because the vapor pressure of these molecules is determined primarily by the number of carbon atoms and the molecular functionalities, various isomers should have similar vapor pressures. For the first generation products we calculate vapor pressures for the $\mathrm{C}_{5}$ compounds of $13-0.97 \mathrm{~Pa}$, and for the $\mathrm{C}_{10}$ peroxide, $4.1 \times 10^{-3} \mathrm{~Pa}$. For the second generation products with 4 functional groups, we calculate $5.2 \times 10^{-5}-9.7 \times 10^{-5} \mathrm{~Pa}$ for the $\mathrm{C}_{5}$ compounds, and $1.3 \times 10^{-11} \mathrm{~Pa}$ for the $\mathrm{C}_{10}$. Also in Fig. 9 for each molecule we show the molecular weight (Da, black), and effective saturation concentration $C^{*}\left(\mu \mathrm{g} \mathrm{m}^{-3}\right.$, green). From the effective saturation we calculate the fraction of this molecule residing in the particle phase in the presence of $0.52 \mu \mathrm{g} \mathrm{m}^{-3}$ organic aerosol (red), which was the actual (not dilution corrected) OA at 16:30. Vapor pressures are estimated using the group contribution method (Pankow and Asher, 2008) which has been demonstrated to estimate these values to within a factor of 2 for 456 atmospheric compounds spanning 14 orders of magnitude in $P_{L}^{0}$. The vapor pressure 
is related to an equilibrium partitioning coefficient $(K)$ and to the effective saturation concentration $\left(C^{*}\right)$ by

$$
K=\frac{1}{C^{*}}=\frac{760 R T}{M W_{\mathrm{om}} 10^{6} \xi P_{L}^{0}}
$$

with $R$ being the ideal gas constant $\left(8.206 \times 10^{-5} \mathrm{~m}^{3} \mathrm{~atm} \mathrm{~mol}^{-1} \mathrm{~K}^{-1}\right), \quad T$ is the temperature $(\mathrm{K}), M W_{\mathrm{om}}$ is the mean molecular weight of the organic aerosol $\left(\mathrm{g} \mathrm{mol}^{-1}\right)$ and $\xi$ is the activity coefficient of the species in the organic aerosol phase, which is typically assumed to be 1 (Odum et al., 1996). For these calculations we assume $M W_{\mathrm{Om}}=226 \mathrm{~g} \mathrm{~mol}^{-1}$ which is the molecular weight of the $\mathrm{C}_{5}$ dinitrate-diol. The fraction of a given molecule $i$ which is residing in the OA phase $\left(Y_{i}\right)$ is then calculated under these assumptions using the relationship between $C^{*}$, the particle phase $\left(C_{p}\right)$ and gas phase $\left(C_{g}\right)$ concentrations of species, and the ambient OA concentration $\left(M_{0}\right)$ :

$$
\begin{aligned}
& \frac{1}{C^{*}}=\frac{C_{p}}{C_{g} M_{0}} \\
& Y_{i}=\frac{M_{0} / C^{*}}{1+M_{0} / C^{*}}
\end{aligned}
$$

At low concentrations of aerosol, the yield calculated as a function of vapor pressure is highly sensitive to both $M_{0}$ and $M W_{\mathrm{om}}$. For example, in Fig. 9 we state that for $M W_{\mathrm{O}}=226$ and $M_{0}=0.52 \mu \mathrm{g} \mathrm{m}^{-3}, Y_{i}=5.6 \%$. Varying $M_{0}$ from $0.4-0.6 \mu \mathrm{g} \mathrm{m}^{-3}$ with $M W_{\text {om }}$ fixed at $226 \mathrm{~g} / \mathrm{mol}$ we calculate $Y_{i}=4-6 \%$ for this compound. If instead we hold $M_{0}$ fixed at $0.52 \mu \mathrm{g} \mathrm{m}^{-3}$ and vary $M W_{\mathrm{O}}$ in the range 150 $300 \mathrm{~g} / \mathrm{mol}$, we calculate $Y_{i}=4-8 \%$. Generally, given uncertainties in $M W_{\mathrm{Om}}$ and $M_{0}$ we find that equilibrium partitioning predicts yields of $\ll 1 \%$ for the first generation products, $\approx 4-20 \%$ for the second generation $\mathrm{C}_{5}$ products, and $>95 \%$ for the $\mathrm{C}_{10}$ peroxides. Considering the factor of two uncertainty in the vapor pressures of the oxidation products and the assumption that $\xi=1$, we find these predicted yields reasonably close to the $4 \pm 2 \%$ molar yield observed and conclude that the primary components of the aerosol are most likely $\mathrm{C}_{5}$ second generation oxidation products. The yields that would have been observed if the aerosol was primarily composed of first generation oxidation products or highly functionalized peroxides are well outside of this range. Figure 10 shows the AMS nitrate vs AMS organic signals from UTC 14:1524:00. A linear fit to the data indicates that the ratio of nitrate:organic of the SOA (on a mass basis) was approximately 0.18 . The production of SOA with a nitrate:organic ratio of 0.18 could in principle be due to condensation either of a single nitrate containing organic compound with this ratio, or by co-condensation of multiple oxidation products. In Fig. 9 (purple numbers) we have estimated the nitrate:organic mass ratio that would be observed for the presumed second generation products, assuming that $\mathrm{RONO}_{2}$ fragments in the

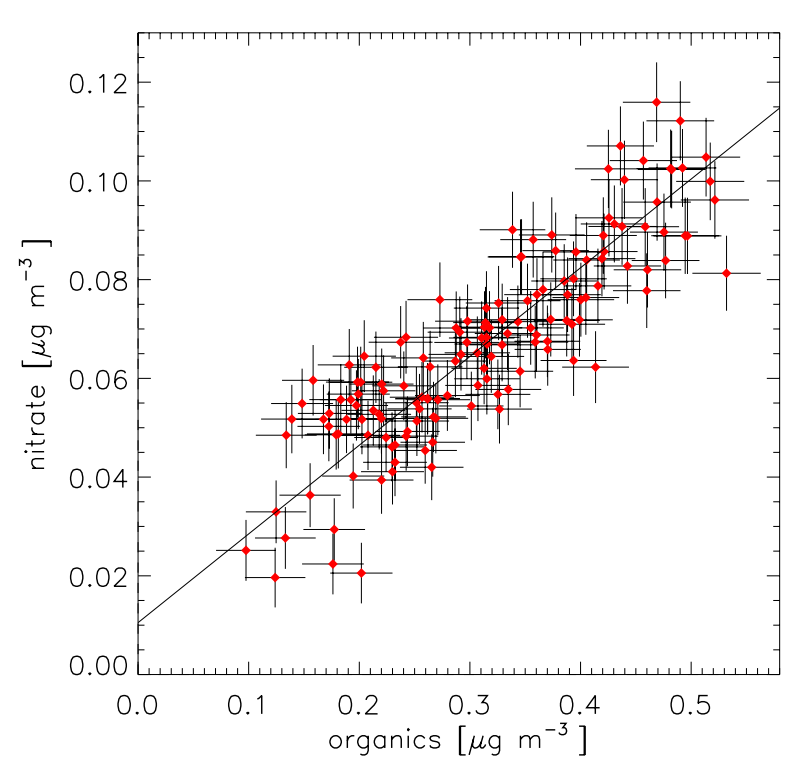

Fig. 10. AMS organic aerosol vs. AMS nitrate alkoxy following $14: 15$ UTC. A linear fit to the data yields a slope of $0.180 \pm 0.007$, $R^{2}=0.76, \chi^{2} / N=1.19$.

AMS as $\mathrm{R}$ (organic) and $\mathrm{ONO}_{2}$ (nitrate) and each are detected with equal efficiency. The calculated values are shown in purple. All molecules have nitrate:organic mass ratios $>1$, much too large to explain the observations. Fragmentation of organic nitrates $\mathrm{RONO}_{2} \rightarrow \mathrm{RO}+\mathrm{NO}_{2}$ on the AMS heater is likely, which would reduce these ratios somewhat by reducing the nitrate mass and increasing the organic mass by $16 \mathrm{~g} / \mathrm{mol}$ (one $\mathrm{O}$ atom) for each nitrate group. For example, the dinitrate-diol structure of $M W 226$ would in this case have a nit:org ratio of 0.69 instead of 1.2. This however is still much higher than our observed 0.18 . The discrepancy here could be explained by a number of mechanisms, including: 1) co-condensation of nitrate and non-nitrate organics, 2) polymerization of the nitrate peroxy radicals with nonnitrate containing species, or some other addition of nonnitrate functional groups to the isoprene oxidation products, 3 ) underestimation of the nitrate content in the aerosol, or 4) release of nitrogen upon condensation of organic nitrates.

Isoprene $\left(\mathrm{C}_{5} \mathrm{H}_{8}\right)$ and nitrate radical $\left(\mathrm{NO}_{3}\right)$ respectively have molecular weights of 68 , and 62. If a single molecule is forming the SOA through the addition of one nitrate radical followed by the polymerization of isoprene units, this would be somewhere between 5 and 6 isoprene units $(0.18$ and 0.15 nitrate/organic mass respectively). Even if we assume that oxidation of each double bond of isoprene adds 2 oxygens to the mass $\left(\mathrm{C}_{5} \mathrm{H}_{8} \mathrm{O}_{4}, \mathrm{MW}=132\right)$ this would require at least two fully oxidized isoprenes per nitrate group. Laboratory studies have observed the formation of polymers in SOA from isoprene (Surratt et al., 2006) and other precursor VOC's (Jang et al., 2002; Kalberer et al., 2004; Muller et al., 


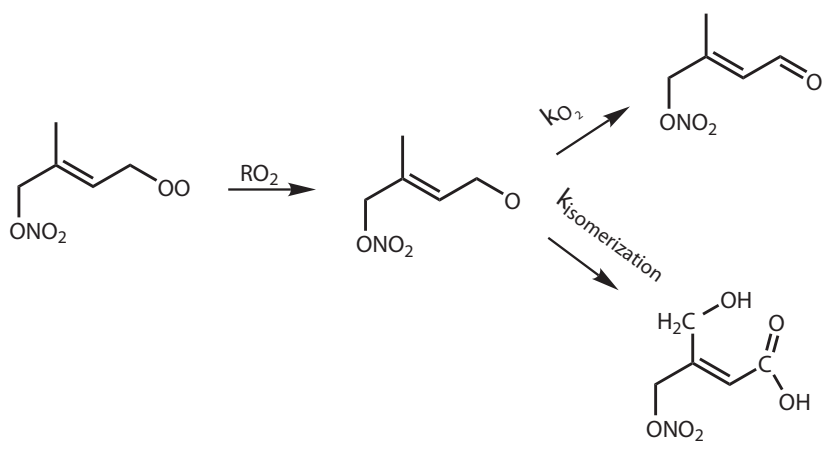

Fig. 11. Isomerization vs. decomposition of the nitrate oxy radical. Multiple steps in the isomerization channel are left out of diagram for simplicity. Only final stable products are shown.

2008) by various mechanisms some of which may be possibilities here.

An internal isomerization of the $\delta$-alkoxy radical formed by $\mathrm{NO}_{3}$ addition to isoprene at the 1 position via a 6 membered ring is also a possibility for adding non-nitrate functionality to the oxidation products (Fig. 11). Such isomerizations have been suggested as responsible for observed products from the isoprene $+\mathrm{NO}_{3}$ reaction in the studies of Kwok et al. (1996) and Ng et al. (2008). This could lead to a slight decrease in the nitrate:organic ratio: $0.93 \mathrm{vs}$ the 1.2 for example if the second double bond of the two products shown in Fig. 11 reacts again with $\mathrm{NO}_{3}$. Atkinson (2007) recommends estimated rates of internal isomerization vs. reaction with $\mathrm{O}_{2}$ for alkoxy radicals based on a structure-reactivity relationship and these rates can in principle be used to estimate the relative importance of the products formed from these two different alkoxy reaction channels. The recommended reaction rate with $\mathrm{O}_{2}$ at $298 \mathrm{~K}$ is $k_{\mathrm{O}_{2}}=9 \times 10^{-15}$ molecule ${ }^{-1} \mathrm{~cm}^{3} \mathrm{~s}^{-1}$ so that at $21 \% \mathrm{O}_{2}$ and standard conditions, $k_{\mathrm{O}_{2}}\left[\mathrm{O}_{2}\right]=4.6 \times 10^{4} \mathrm{~s}^{-1}$. The recommended isomerization rate is $k_{\text {isom. }}=3.2 \times 10^{5} \mathrm{~s}^{-1}$, nearly 7 times as fast as the reaction with $\mathrm{O}_{2}$, suggesting that molecules formed from the rearrangement might be expected to account for a significant fraction of the carbon balance. The production of this molecule as a main product of the isoprene $+\mathrm{NO}_{3}$ reaction would not be in conflict with previous product studies for which organic nitrate standards were not available and for which the product chemical structure has been deduced based on the existence of carbonyl and nitrate peaks in FTIR spectra. $\mathrm{Ng}$ et al. (2008) however do not report significant yields of this product, even though it would have been likely to be detected by their CIMS with comparable efficiency to other products that are reported. Perring et al. (2009) do not report this either, though carbon closure in that experiment is reported to be within $10 \%$.

$\mathrm{Ng}$ et al. (2008) reported observing many multifunctional organic nitrates and dinitrates in both the gas phase, and on filter samples produced in their isoprene $+\mathrm{NO}_{3}$ experiment. Although an AMS nitrate:organic ratio for this experiment was not reported, and it is possible that there were many unidentified products, all of the structures observed with their CIMS and filter extraction TOFMS have much higher nitrate:organic ratios than we measured. Furthermore, as we have observed in the initial reaction, and as is well founded for many alkene $\mathrm{NO}_{3}$ reactions, the yield of organic nitrate formation from these reactions is high. The continued oxidation of double bond containing isoprene oxidation products is expected to lead to the formation of organic nitrates. Therefore it seems most reasonable that the condensing species were similar to the $\mathrm{C}_{5}$ dinitrate species in Fig. 9. Our data can neither confirm nor deny the possibility of release of $\mathrm{NO}_{\mathrm{X}}$ during SOA formation due to rapid changes in total $\mathrm{NO}_{2}$ which would have been only contributed to in a minor way from this process. While AMS nitrogen:carbon and oxygen:carbon ratios have been verified for nitrogen containing compounds including amines, amides and phenols, (Aiken et al., 2007) similar results have not been reported for molecules containing $\mathrm{RONO}_{2}$ groups, leaving open the possibility that organic nitrate content is underestimated.

\section{Atmospheric implications}

Our observations indicate that the formation of SOA from isoprene $+\mathrm{NO}_{3}$ under typical concentrations of $\mathrm{OA}$ will rely on the extent to which both double bonds of isoprene are oxidized. Here, we observed oxidation of both bonds via reaction with $\mathrm{NO}_{3}$. However, the exchange of a nitrate group with a hydroxy group has a minor affect on the effective saturation concentration, thus we expect that reaction with $\mathrm{NO}_{3}$ followed by reaction with $\mathrm{OH}$ or vice versa would produce a similar aerosol yield. To consider the extent to which these second oxidation steps will take place in the atmosphere, we compare the lifetime of the initial oxidation products to reaction with $\mathrm{OH}$ and $\mathrm{NO}_{3}$ to their lifetimes with respect to wet and dry deposition.

MCM uses a rate constant for 4-nitrooxy-3-methyl-2butanal with $\mathrm{OH}$ of $4.16 \times 10^{-11}$ molecules ${ }^{-1} \mathrm{~cm}^{3} \mathrm{~s}^{-1}$. This rate is roughly consistent with those measured by Treves and Rudich (2003) for unsaturated hydroxyalkyl nitrates. At an average daytime concentration of $2 \times 10^{6}$ molecules $/ \mathrm{cm}^{3}$ this would give a lifetime to $\mathrm{OH}$ of $3.3 \mathrm{~h}$, indicating these compounds generated at night by $\mathrm{NO}_{3}$ chemistry remaining through the next morning would be consumed by reaction with $\mathrm{OH}$ early in the day.

We found an effective rate constant for the initial oxidation products with $\mathrm{NO}_{3}$ of $7.0 \times 10^{-14}$ molecules ${ }^{-1} \mathrm{~cm}^{3} \mathrm{~s}^{-1}$. Nighttime $\mathrm{NO}_{3}$ concentrations are highly variable ranging from 0 to hundreds of pptv, and depend on the availability of $\mathrm{NO}_{\mathrm{X}}$. In a recent study Brown et al. (2009) show that the first generation daytime isoprene oxidation products MVK and MACR, are found at ppb levels along with 50-100 ppt 
$\mathrm{NO}_{3}$. This range of $\mathrm{NO}_{3}$ concentrations would yield 3.1$1.6 \mathrm{~h}$ for lifetimes of isoprene nitrates.

We use the method of Brimblecombe and Dawson (1984) to estimate the wet deposition rate of the first generation oxidation products. This method has been used previously to estimate the wet removal rate of hydroxy-nitrate isoprene oxidation products (Shepson et al., 1996). Henry's law coefficients at $283 \mathrm{~K}$ of 4-nitrooxy-3-methyl-2-butanal $\left(2.3 \times 10^{4} \mathrm{M} / \mathrm{atm}\right)$ and 4nitrooxy-3-methyl-2-butanol $\left(3.3 \times 10^{5} \mathrm{M} / \mathrm{atm}\right)$ were calculated using the SPARC online calculator (Hilal et al., 2003, 2004). Using the same assumptions for mid-latitude meteorology as Shepson et al. (1996) and Brimblecombe and Dawson (1984), we use these Henry's law constants to calculate rainout rates of $2.3 \times 10^{-6} \mathrm{~s}^{-1}$ for the carbonyl-nitrate and $5.5 \times 10^{-6} \mathrm{~s}^{-1}$ for the hydroxy-nitrate. These rates imply rainout lifetimes of these species of 5 and 2.1 days respectively, both which are too slow to compete with the lifetime to reaction.

Lifetimes to dry deposition are perhaps less well constrained, although we note that loss to dry deposition is unlikely at night because most of the isoprene $+\mathrm{NO}_{3}$ reaction will take place above the nocturnal boundary layer. Dry deposition velocities $\left(v_{d}\right)$ of $\mathrm{HNO}_{3}$ have been reported in the range of 2-4 $\mathrm{cm} \mathrm{s}^{-1}$ (Seinfeld and Pandis, 1998; Farmer and Cohen, 2008), while reported PAN deposition velocities range from $0.25-0.8 \mathrm{~cm} \mathrm{~s}^{-1}$ (Turnipseed et al., 2006; Garland and Penkett, 1976; Farmer and Cohen, 2008; Wolfe et al., 2008). Multi-functional nitrate deposition velocity have been measured by Shepson et al. (1996) and Farmer and Cohen (2008) at $0.4 \mathrm{~cm} \mathrm{~s}^{-1}$ and $2.0 \mathrm{~cm} \mathrm{~s}^{-1}$ respectively, and inferred from $\mathrm{NO}_{y}$ fluxes by Munger et al. (1996) ranging from $0.5 \mathrm{~cm} \mathrm{~s}^{-1}$ at night to $2 \mathrm{~cm} \mathrm{~s}^{-1}$ during the day. Assuming the same scale height as we use for the wet deposition calculation $(2.3 \mathrm{~km})$ the lifetime $\left(\tau=Z / v_{d}\right.$ where $Z=$ scale height) for $v_{d}$ of $0.25-2.0 \mathrm{~cm} \mathrm{~s}^{-1}$ would be 10-1.3 days if it were important.

These estimates of wet and dry deposition lifetimes of the carbonyl- and hydroxy-nitrate first generation oxidation products of isoprene are significantly longer than lifetimes to chemical reaction by average daytime $\mathrm{OH}$ concentrations, and $\mathrm{NO}_{3}$ concentration greater than 10 ppt. For $\mathrm{NO}_{3}$ above $10 \mathrm{ppt}$ the first generation oxidation products are likely to react with $\mathrm{NO}_{3}$ at night converting them to condensible species, but on timescales longer than the rapid reaction of isoprene with $\mathrm{NO}_{3}$ that has been observed immediately after sunset. For much smaller $\mathrm{NO}_{3}$ concentrations, transport at night, daytime deposition or $\mathrm{OH}$ oxidation will dominate the fate of these nitrates.

\section{Summary and conclusions}

We have observed the reaction of isoprene with nitrate radicals at atmospherically relevant concentrations of VOC and

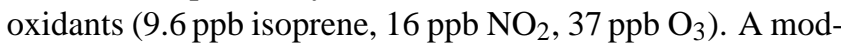
ified version of the MCM was used to evaluate the yields for alkyl nitrates from the reaction of isoprene with $\mathrm{NO}_{3}(70 \%)$ and for the subsequent reaction of the first generation oxidation products with $\mathrm{NO}_{3}(20-60 \%)$. Alkyl nitrate observations which were significantly lower than predicted by the MCM were used to determine an effective rate constant for reaction of the group of first generation oxidation products with $\mathrm{NO}_{3}$. We observed that SOA is formed from the isoprene/ $\mathrm{NO}_{3}$ system, but at low organic aerosol concentration $\left(<1 \mu \mathrm{g} / \mathrm{m}^{3}\right)$, only when both double bonds of isoprene are oxidized. Using the modified MCM, we estimate that the SOA mass yield of isoprene which reacts two times with $\mathrm{NO}_{3}$ is $14 \%$ and show that this yield is consistent with equilibrium partitioning of the expected oxidation products. Modeling also indicates an inconsistency between the current estimations of the relative magnitudes of the rate constants for $\mathrm{RO}_{2}+\mathrm{RO}_{2}$ vs. $\mathrm{RO}_{2}+\mathrm{HO}_{2}$, and the expectation that $\mathrm{RO}_{2}+\mathrm{HO}_{2} \rightarrow \mathrm{ROOH}$ with a $100 \%$ yield. The AMS data reported much less nitrate content than would be expected from these structures, and we therefore conclude that either some additional chemistry was responsible for the chemical content of the SOA, or the aerosol nitrogen content is higher than measured.

Acknowledgements. The Berkeley authors were supported by NSF ATM-0639847 and NSF ATM-0511829. The authors would like to thank the SAPHIR $\mathrm{NO}_{3}$ intercomparison campaign team for organizing and administering the experiments in June 2007 at Forschungszentrum Jülich. This work was a joint activity of the European Community Network of Excellence ACCENT, grant no. GOCE CT-2004-505337 and the EUROCHAMP project.

Edited by: J. Abbatt

\section{References}

Aiken, A., DeCarlo, P., and Jimenez, J.: Elemental Analysis of Organic Species with Electron Ionization High-Resolution Mass Spectrometry, Anal. Chem., 79, 8350-8358, 2007.

Alfarra, M. R., Paulsen, D., Gysel, M., Garforth, A. A., Dommen, J., Prévôt, A. S. H., Worsnop, D. R., Baltensperger, U., and Coe, H.: A mass spectrometric study of secondary organic aerosols formed from the photooxidation of anthropogenic and biogenic precursors in a reaction chamber, Atmos. Chem. Phys., 6, 52795293, 2006,

http://www.atmos-chem-phys.net/6/5279/2006/.

Apodaca, R. L., Simpson, W., Ball, S. M., Brauers, T., Brown, S. S., Cohen, R. C., Crowley, J., Dorn, H.-P., Dubé, W. P., Fry, J. L., Fuchs, H., Haseler, R., Heitmann, U., Kato, S., Kajii, Y., Kiendler-Scharr, A., Kleffmann, J., Labazan, I., Matsumoto, J., Nishida, S., Rollins, A. W., Tillmann, R., Wahner, A., Wegener, R., and Wooldridge, P. J.: Intercomparison of $\mathrm{N}_{2} \mathrm{O}_{5}$ sensors using SAPHIR reaction chamber, in preparation, 2009. 
Atkinson, R.: Rate constants for the atmospheric reactions of alkoxy radicals: An updated estimation method, Atmos. Environ., 41, 8468-8485, 2007.

Atkinson, R., Aschmann, S. M., Winer, A. M., and Pitts, J. N. J.: Kinetics of the Gas-Phase Reactions of $\mathrm{NO}_{3}$ Radicals with a Series of Dialkenes, Cycloalkenes, and Monoterpenes at $295 \pm 1 \mathrm{~K}$, Environ. Sci. Technol., 18, 370-375, 1984.

Atkinson, R., Baulch, D. L., Cox, R. A., Crowley, J. N., Hampson, R. F., Hynes, R. G., Jenkin, M. E., Rossi, M. J., Troe, J., and Wallington, T. J.: Evaluated kinetic and photochemical data for atmospheric chemistry: Volume IV - gas phase reactions of organic halogen species, Atmos. Chem. Phys., 8, 4141-4496, 2008 , http://www.atmos-chem-phys.net/8/4141/2008/.

Barnes, I., Bastian, V., Becker, K. H., and Tong, Z.: Kinetics and Products of the Reactions of $\mathrm{NO}_{3}$ with Monoalkenes, Dialkenes, and Monoterpenes, J. Phys. Chem., 94, 2413-2419, 1990.

Benter, T. and Schindler, R. N.: Absolute rate coefficients for the reaction of $\mathrm{NO}_{3}$ radicals with simple dienes, Chem. Phys. Lett., 145, 67-70, 1988.

Berndt, T. and Boge, O.: Gas-Phase Reaction of $\mathrm{NO}_{3}$ Radicals With Isoprene: A Kinetic and Mechanistic Study, Int'1. J. Chem. Kin., 29, 755-765, 1997.

Bey, I., Aumont, B., and Toupance, G.: A modeling study of the nighttime radical chemistry in the lower continental troposphere 1. Development of a detailed chemical mechanism including nighttime chemistry, J. Geophys. Res., 106, 9959-9990, 2001.

Bossmeyer, J., Brauers, T., Richter, C., Rohrer, F., Wegener, R., and Wahner, A.: Simulation chamber studies on the $\mathrm{NO}_{3}$ chemistry of atmospheric aldehydes, Geophys. Res. Lett., 33, L18810, doi: 10.1029/2006GL026778, 2006.

Brimblecombe, P. and Dawson, G. A.: Wet Removal of Highly Soluble Gases, J. of Atmos. Chem., 2, 95-107, 1984.

Brown, S. S., Stark, H., Circiora, S. J., and Ravishankara, A. R.: Insitu measurement of atmospherc $\mathrm{NO}_{3}$ and $\mathrm{N}_{2} \mathrm{O}_{5}$ via cavity ringdown spectroscopy, Geophys. Res. Lett, 28, 3227-3230, 2001.

Brown, S. S., Osthoff, H. D., Stark, H., Dube, W. P., Ryerson, T. B., Warneke, C., de Gouw, J. A., Wollny, A. G., Parrish, D. D., Fehsenfeld, F. C., and Ravishankara, A. R.: Aircraft observations of daytime $\mathrm{NO}_{3}$ and $\mathrm{N}_{2} \mathrm{O}_{5}$ and their implications for tropospheric chemistry, Journal of Photochemistry and Photobiology A: Chemistry, 176, 270-278, 2005.

Brown, S. S., deGouw, J. A., Warneke, C., Ryerson, T. B., Dubé, W. P., Atlas, E., Weber, R. J., Peltier, R. E., Neuman, J. A., Roberts, J. M., Swanson, A., Flocke, F., McKeen, S. A., Brioude, J., Sommariva, R., Trainer, M., Fehsenfeld, F. C., and Ravishankara, A. R.: Nocturnal isoprene oxidation over the Northeast United States in summer and its impact on reactive nitrogen partitioning and secondary organic aerosol, Atmos. Chem. Phys., 9, 30273042, 2009, http://www.atmos-chem-phys.net/9/3027/2009/.

Canagartna, M., Jayne, J., Jimenez, J., Allan, J., Alfarra, M., Zhang, Q., Onaxch, T., Drewnick, F., Coe, H., Middlebrook, A., Delia, A., Williams, L., Trimborn, A., Northway, M., DeCarlo, P., Kolb, C., Davidovits, P., and Worsnop, D.: Chemical and microphysical characteriation of ambient aerosols with the aerodyne aerosol mass spectrometer, Mass Spectrom. Rev., 26, 185-222, 2007.

Chameides, W. L., Lindsay, R. W., Richardson, J., and Kiang, C. S.: The Role of Biogenic Hydrocarbons in Urban Photochemical
Smog: Atlanta as a Case Study, Science, 241, 1473-1475, 1988. Cottrell, L. D., Griffin, R. J., Jimenez, J., Zhang, Q., Ulbrich, I., Ziemba, L. D., Beckman, P. J., Sive, B. C., and Talbot, R. W.: Submicron particles at Thompson Farm during ICARTT measured using aerosol mass spectrometry, J. Geophys. Res., 113, D08212, doi:10.1029/2007JD009192., 2008.

Crowley, J. N. and Dillon, T. J.: Direct detection of $\mathrm{OH}$ formation in the reactions of $\mathrm{HO}_{2}$ with $\mathrm{CH}_{3} \mathrm{C}(\mathrm{O}) \mathrm{O}_{2}$ and other substituted peroxy radicals, Atmos. Chem. Phys., 8, 4877-4889, 2008, http://www.atmos-chem-phys.net/8/4877/2008/.

D’Anna, B., Andresen, O., Gefen, Z., and Nielsen, C. J.: Kinetic study of $\mathrm{OH}$ and $\mathrm{NO}_{3}$ radical reactions with 14 aliphatic aldehydes, Phys. Chem. Chem. Phys., 3, 3057-3063, 2001.

Day, D. A., Wooldridge, P. J., Dillon, M., Thornton, J. A., and Cohen, R. C.: A thermal dissociation laser-induced fluorescence instrument for in situ detection of $\mathrm{NO}_{2}$, peroxy nitrates, alkyl nitrates, and $\mathrm{HNO}_{3}$, J. Geophys. Res., 107(D6), 4046, doi:10.1029/2001JD000779, 2002.

DeCarlo, P. F., Kimmel, J. R., Trimborn, A., Northway, M. J., Jayne, J. T., Aiken, A. C., Gonin, M., Fuhrer, K., Horvath, T., Docherty, K. S., Worsnop, D. R., and Jimenez, J. L.: Field-Deployable, High-Resolution, Time-of-Flight Aerosol Mass Spectrometer, Anal. Chem., 78, 8281-8289, 2006.

Dlugokencky, E. J. and Howard, C. J.: Studies of $\mathrm{NO}_{3}$ Radical Reactions with Some Atmospheric Organic Compounds at Low Pressures, J. Phys. Chem, 93, 1091-1096, 1989.

Dorn, H.-P., Apodaca, R. L., Ball, S. M., Brauers, T., Brown, S. S., Cohen, R. C., Crowley, J., Dubé, W. P., Fry, J. L., Fuchs, H., Haseler, R., Heitmann, U., Jones, R., Kato, S., Kajii, Y., Kiendler-Scharr, A., Labazan, I., Matsumoto, J., Meinen, J., Nishida, S., Platt, U., Rohrer, R., Rollins, A. W., Ruth, A. A., Schlosser, E., Schuster, G., Schillings, A., Simpson, W., Thieser, J., Tillmann, R., Varma, R., Venables, D., Wahner, A., Wegener, R., and Wooldridge, P. J.: Intercomparison of $\mathrm{NO}_{3}$ measurement techniques at the simulation chamber SAPHIR, in preparation, 2009.

Dubé, W. P., Brown, S. S., Osthoff, H. D., Nunley, M. R., Circiora, S. J., Paris, M. W., McLaughlin, R. J., and Ravishankara, A. R.: Aircraft instrument for simultaneous, in situ measurement of $\mathrm{NO}_{3}$ and $\mathrm{N}_{2} \mathrm{O}_{5}$ via pulsed cavity ring-down spectroscopy, Rev. Sci. Inst., 77, 034101, 2006.

Farmer, D. K. and Cohen, R. C.: Observations of $\mathrm{HNO}_{3}, \Sigma \mathrm{AN}$, $\Sigma \mathrm{PN}$ and $\mathrm{NO}_{2}$ fluxes: evidence for rapid HOx chemistry within a pine forest canopy, Atmos. Chem. Phys., 8, 3899-3917, 2008, http://www.atmos-chem-phys.net/8/3899/2008/.

Fiore, A. M., Horowitz, L. W., Purves, D. W., Levy, H. I., Evans, M. J., Want, Y., Li, Q., and Yantosca, R. M.: Evaluating the contribution of changes in isoprene emissions to surface ozone trends over the eastern United States, J. Geophys. Res., 110, D12303, doi:10.1029/2004JD005485, 2005.

Fry, J. L., Kiendler-Scharr, A., Rollins, A. W., Wooldridge, P. J., Brown, S. S., Fuchs, H., Dubé, W., Mensah, A., dal Maso, M., Tillmann, R., Dorn, H.-P., Brauers, T., and Cohen, R. C.: Organic nitrate and secondary organic aerosol yield from $\mathrm{NO}_{3}$ oxidation of $\beta$-pinene evaluated using a gas-phase kinetics/aerosol partitioning model, Atmos. Chem. Phys., 9, 1431-1449, 2009, http://www.atmos-chem-phys.net/9/1431/2009/.

Fuchs, H., Dubé, W., Ciciora, S., and Brown, S.: Determination of Inlet Transmission and Conversion Efficiencies for in Situ Mea- 
surements of the Nocturnal Nitrogen Oxides, $\mathrm{NO}_{3}, \mathrm{~N}_{2} \mathrm{O}_{5}$ and $\mathrm{NO}_{2}$ via Pulsed Cavity Ring-Down Spectroscopy, Anal. Chem., 80, 6010-6017, 2008.

Fuentes, J. D., Wang, D., Bowling, D. R., Potosnak, M., Monson, R. K., Goliff, W. S., and Stockwell, W. R.: Biogenic Hydrocarbon Chemistry within and Above a Mixed Desciduous Forest, J. Atmos. Chem., 56, 165-185, doi:10.1007/s10874-006-9048-4, 2007.

Garland, J. A. and Penkett, S. A.: Absorption of peroxy acetyl nitrate and ozone by natural surfaces, Atmos. Environ., 10, $1127-$ 1131, 1976.

Geyer, A., Alicke, B., Ackermann, R., Martinez, M., Harder, H., Brune, W., di Carlo, P., Williams, E., Jobson, T., Hall, S., Shetter, R., and Stutz, J.: Direct observations of daytime $\mathrm{NO}_{3}$ : Implications for urban boundary layer chemistry, J. Geophys. Res., 108(D12), 4368, doi:10.1029/2002JD002967, 2003a.

Geyer, A., Bächmann, K., Hofzumahaus, A., Holland, F., Konrad, S., Klüpfel, T., Pätz, H.-W., Perner, D., Mihelcic, D., Schäfer, H.-J., Volz-Thomas, A., and Platt, U.: Nighttime formation of peroxy and hydroxyl radicals during the BERLIOZ campaign: Observations and modeling studies, J. Geophys. Res., 108(D4), 8249, doi:10.1029/2001JD000656, 2003b.

Gómez-González, Y., Surratt, J. D., Ceyckens, F., Szmigielski, R., Vermeylen, R., Jaoui, M., Lewandowski, M., Offenberg, J. H., Kleindienst, T. E., Edney, E. O., Blockhuys, F., Alsenoy, C. V., Maenhaut, W., and Claeys, M.: Characterization of organosulfates from the photooxidation of isoprene and unsaturated fatty acids in ambient aerosol using liquid chromatography/(-) electrospray ionization mass spectrometry, J. Mass Spectrom, 43, 371382,2008

Guenther, A., Hewitt, C. N., Erickson, D., Fall, R., Geron, C., Graedel, T., Harley, P., Klinger, L., Lerdau, M., McKay, W. A., Pierce, T., Scholes, B., Steinbrecher, R., Tallamraju, R., Taylor, J., and Zimmerman, P.: A global model of natural volatile organic compound emissions, J. Geophys. Res., 100, 8873-8892, 1995.

Guenther, A., Karl, T., Harley, P., Wiedinmyer, C., Palmer, P. I., and Geron, C.: Estimates of global terrestrial isoprene emissions using MEGAN (Model of Emissions of Gases and Aerosols from Nature), Atmos. Chem. Phys, 6, 3181-3210, 2006.

Hasson, A. S., Tyndall, G. S., and Orlando, J. J.: A Product Yield Study of the Reaction of $\mathrm{HO}_{2}$ Radicals with Ethyl Peroxy $\left(\mathrm{C}_{2} \mathrm{H}_{5} \mathrm{O}_{2}\right)$, Acetyl peroxy $\left(\mathrm{CH}_{3} \mathrm{C}(\mathrm{O}) \mathrm{O}_{2}\right)$, and Acetonyl Peroxy $\left(\mathrm{CH}_{3} \mathrm{C}(\mathrm{O}) \mathrm{CH}_{2} \mathrm{O}_{2}\right)$ Radicals, J. Phys. Chem. A., 108, 59795989, 2004.

Hasson, A. S., Kuwata, K. T., Arroyo, M. C., and Petersen, E. B.: Theoretical studies of the reaction of hydroperoxy radicals $\left(\mathrm{HO}_{2}\right)$ with ethyl peroxy $\left(\mathrm{CH}_{3} \mathrm{CH}_{2} \mathrm{O}_{2}\right)$, acetyl peroxy $\left(\mathrm{CH}_{3} \mathrm{C}(\mathrm{O}) \mathrm{O}_{2}\right)$, and acetonyl peroxy $\left(\mathrm{CH}_{3} \mathrm{C}(\mathrm{O}) \mathrm{CH}_{2} \mathrm{O}_{2}\right)$ radicals, J. Photochem. and Photobio. A: Chemistry, 176, 218-230, 2005.

Henze, D. K. and Seinfeld, J. H.: Global secondary organic aerosol from isoprene oxidation, Geophys. Res. Lett., 33, L09812, doi: 10.1029/2006GL025976, 2006.

Hilal, S. H., Carreira, L. A., and Karickhoff, S. W.: Prediction of the Vapor Pressure, Boiling Point, heat of Vaporization and Diffusion Coefficient of Organic Compounds, QSAR \& Combinatorial Science, 22, 565-574, 2003.

Hilal, S. H., Carreira, L. A., and Karickhoff, S. W.: Prediction of the Solubility, Activity Coefficient, Gas/Liquid and Liq-
uid/Liquid Distribution Coefficients of Organic Compounds, QSAR \& Combinatorial Science, 23, 709-720, 2004.

Horowitz, L. W., Liang, J., Gardner, G. M., and Jacob, D. J.: Export of reactive nitrogen from North America during summertime: Sensitivity to hydrocarbon chemistry, J. Geophys. Res., 103, 13451-13476, 1998.

Horowitz, L. W., Fiore, A. M., Milly, G. P., Cohen, R. C., Perring, A., Wooldridge, P. J., Hess, P. G., Emmons, L. K., and Lamarque, J. L.: Observational constraints on the chemistry of isoprene nitrates over the eastern United States, J. Geophys. Res., 112, D12S08, doi:10.1029/2006JD007747, 2007.

Jang, M., Czoschke, N. M., Lee, S., and Kamens, R. M.: Heterogeneous Atmospheric Aerosol Production by Acid-Catalyzed Particle-Phase Reactions, Science, 298, 814-817, 2002.

Jenkin, M. E., Hurley, M. D., and Wallington, T. J.: Investigation of the radical product channel of the $\mathrm{CH}_{3} \mathrm{C}(\mathrm{O}) \mathrm{O}_{2}+\mathrm{HO}_{2}$ reaction in the gas phase, Phys. Chem. Chem. Phys., 9, 3149-3162, 2007.

Kalberer, M., Paulsen, D., Saz, M., Steinbacher, M., Dommen, J., Prévôt, A. S. H., Fisseha, R., Weingartner, E., Frankevich, V., Zenobi, R., and Baltensperger, U.: Identification of Polymers as Major Components of Atmospheric Organic Aerosols, Science, 303, 1659-1662, 2004.

Kroll, J. H., Ng, N. L., Murphy, S. M., Flagan, R. C., and Seinfeld, J. H.: Secondary organic aerosol formation from isoprene photooxidation under high- $\mathrm{NO}_{\mathrm{X}}$ conditions, Geophys. Res. Lett., 32, L18808, doi:10.1029/2005GL023637, 2005.

Kroll, J. H., Ng, L. N., Murphy, S. M., Flagan, R. C., and Seinfeld, J. H.: Secondary Organic Aerosol Formation from Isoprene Photooxidation, Environ. Sci. Technol, 40, 1869-1877, 2006.

Kwok, E. S. C. and Atkinson, R.: Estimation of hydroxyl radical reaction rate constants for gas-phase organic compounds using a structure-reactivity relationship: an update, Atmos. Environ., 29, 1685-1695, 1995.

Kwok, E. S. C., Aschmann, S. M., Arey, J., and Atkinson, R.: Product Formation from the Reaction of the $\mathrm{NO}_{3}$ Radical with Isoprene and Rate Constants for the Reactions of Methacrolein and Methyl Vinyl Ketone with the $\mathrm{NO}_{3}$ Radical, Int'1. J. Chem. Kin., 28, 925-934, 1996.

Lelieveld, J., Butler, T. M., Crowley, J. N., Dillon, T. J., Fischer, H., Ganzeveld, L., Harder, H., Lawrence, M. G., Martinez, M., Taraborrelli, D., and Williams, J.: Atmospheric oxidation capacity sustained by a tropical forest, Nature, 452, 737-740, doi: 10.1038/nature06870, 2008

Muller, L., Reinnig, M.-C., Warnke, J., and Hoffmann, T.: Unambiguous identification of esters as oligomers in secondary organic aerosol formed from cyclohexene and cyclohexene $\alpha$ pinene ozonolysis, Atmos. Chem. Phys., 8, 1423-1433, 2008, http://www.atmos-chem-phys.net/8/1423/2008/.

Munger, J. W., Wofsy, S. C., Bakwin, P. S., Fan, S.-M., Goulden, M. L., Daube, B. C., and Goldstein, A. H.: Atmospheric deposition of reactive nitrogen oxides and ozone in a temperate deciduous forest and a subarctic woodland. 1. Measurements and mechanisms, J. Geophys. Res., 101, 12639-12657, 1996.

Ng, N. L., Kwan, A. J., Surratt, J. D., Chan, A. W. H., Chhabra, P. S., Sorooshian, A., Pye, H. O. T., Crounse, J. D., Wennberg, P. O., Flagan, R. C., and Seinfeld, J. H.: Secondary organic aerosol (SOA) formation from reaction of isoprene with nitrate radicals $\left(\mathrm{NO}_{3}\right)$, Atmos. Chem. Phys., 8, 4117-4140, 2008, http://www.atmos-chem-phys.net/8/4117/2008/. 
Noda, J., Nyman, G., and Langer, S.: Kinetics of the Gas-Phase Reaction of Some Unsaturated Alcohols with the Nitrate Radical, J. Phys. Chem. A, 106, 945-951, 2002.

Odum, J. R., Hoffmann, T., Bowman, F., Collins, D., Flagan, R. C., and Seinfeld, J. H.: Gas/Partitioning and Secondary Organic Aerosol Yields, Environ. Sci. Technol., 30, 2580-2585, 1996.

Olivier, J. G. J., Van Aardenne, J. A., Dentener, F. J., Pagliari, V., Ganzeveld, L. N., and Peters, J. A. H. W.: Recent trends in global greenhouse gas emissions: regional trends 1970-2000 and spatial distribution of key sources in 2000, Environ. Sci., 2, 81-99, 2005.

Pankow, J. F. and Asher, W. E.: SIMPOL.1: a simple group contribution method for predicting vapor pressures and enthalpies of vaporization of multifunctional organic compounds, Atmos. Chem. Phys., 8, 2773-2796, 2008,

http://www.atmos-chem-phys.net/8/2773/2008/.

Perring, A. E., Wisthaler, A., Graus, M., Wooldridge, P. J., Lockwood, A. L., Mielke, L. H., Shepson, P. B., Hansel, A., and Cohen, R. C.: A product study of the isoprene+NO3 reaction, Atmos. Chem. Phys., 9, 4945-4956, 2009,

http://www.atmos-chem-phys.net/9/4945/2009/.

Ridley, B. A., Grahek, F. E., and Walega, J. G.: A Small, HighSensitivity, Medium-Response Ozone Detector Suitable for Measurements from Light Aircraft, J. Atmos. Ocean. Technol., 9, 142-149, 1992.

Rohrer, F., Bohn, B., Brauers, T., Bruning, D., Johnen, F.-J., Wahner, A., and Kleffmann, J.: Characterisation of the photolytic HONO-source in the atmosphere simulation chamber SAPHIR, Atmos. Chem. Phys., 5, 2189-2201, 2005,

http://www.atmos-chem-phys.net/5/2189/2005/.

Sandu, A. and Sander, R.: Technical note: Simulating chemical systems in Fortran90 and Matlab with the Kinetic PreProcessor KPP-2.1, Atmos. Chem. Phys., 6, 187-195, 2006,

http://www.atmos-chem-phys.net/6/187/2006/.

Saunders, S. M., Jenkin, M. E., Derwent, R. G., and Pilling, M. J.: Protocol for the development of the Master Chemical Mechanism, MCM v3 (Part A): tropospheric degradation of nonaromatic volatile organic compounds, Atmos. Chem. Phys., 3, 161-180, 2003,

http://www.atmos-chem-phys.net/3/161/2003/.

Seinfeld, J. H. and Pandis, S. N.: Atmospheric Chemistry and Physics: From Air Pollution to Climate Change, 1998.

Shepson, P. B., Mackay, E., and Muthuramu, K.: Henry's Law Constants and Removal Processes for Several Atmospheric $\beta$ Hydroxy Alkyl Nitrates, Environ. Sci. Technol., 30, 3618-3623, 1996.

Skov, H., Hjorth, J., Lohse, C., Jensen, N. R., and Restelli, G.: Products and mechanisms of the reactions of the nitrate radical $\left(\mathrm{NO}_{3}\right)$ with isoprene, 1,3-butadiene and 2,3-dimethyl-1,3-butadiene in air, Atmos. Environ., 26A, 2771-2783, 1992.

Starn, T. K., Shepson, P. B., Bertman, S. B., Riemer, D. D., Zika, R. G., and Olszyna, K.: Nighttime isoprene chemistry at an urban-impacted forest site, J. Geophys. Res., 103, 22,43722,447, 1998.

Steinbacher, M., Dommen, J., Ordonez, C., Reimann, S., Grüebler, F. C., Staehelin, J., Andreani-Aksoyoglu, S., and Prévôt, A. S. H.: Volatile Organic Compounds in the Po Basin. Part B: Biogenic VOCs, J. Atmos. Chem., 51, 293-315, doi:10.1007/ s10874-005-3577-0, 2005.
Stroud, C. A., Roberts, J. M., Williams, E. J., D., H., Angevine, W. M., Fehsenfeld, F. C., Wisthaler, A., Hansel, A., MartinezHarder, M., Harder, H., Brune, W. H., Hoenninger, G., Stutz, J., and White, A. B.: Nighttime isoprene trends at an urban forested site during the 1999 Southern Oxidant Study, J. Geophys. Res., 107(D16), 4291, doi:10.1029/2001JD00959, 2002.

Suh, I., Lei, W., and Zhang, R.: Experimental and Theoretical Studies of Isoprene Reaction with $\mathrm{NO}_{3}$, J. Phys. Chem. A, 105, 64716478, 2001.

Surratt, J. D., Murphy, S. M., Kroll, J. H., Ng, N. L., Hildebrandt, L., Sorooshian, A., Szmigielski, R., Vermeylen, R., Maenhaut, W., Clayes, M., Flagan, R. C., and Seinfeld, J. H.: Chemical Composition of Secondary Organic Aerosol Formed from the Photooxidation of Isoprene, J. Phys. Chem. A, 110, 9665-9690, 2006.

Surratt, J. D., Gómez-González, Chan, A. W. H., Vermeylen, R., Shahgholi, M., Kleindienst, T. E., Edney, E. O., Offenberg, J. H., Lewandowski, M., Jaoui, M., Maenhaut, W., Claeys, M., Flagan, R. C., and Seinfeld, J. H.: Organosulfate Formation in Biogenic Secondary Organic Aerosol, J. Phys. Chem. A, 112, 8345-8378, 2008.

Thornton, J. A., Wooldridge, P. J., and Cohen, R. C.: Atmospheric $\mathrm{NO}_{2}$ : In Situ laser-Induced Fluorescence Detection at Parts per Trillion Mixing Ratios, Anal. Chem., 72, 528-539, 2000.

Thornton, J. A., Wooldridge, P. J., Cohen, R. C., Martinez, M., Harder, H., Brune, W. H., Williams, E. J., Roberts, J. M., Fehsenfeld, F. C., Hall, S. R., Shetter, R. E., Wert, B. P., and Fried, A.: Ozone production rates as a function of $\mathrm{NO}_{\mathrm{X}}$ abundances and $\mathrm{HO}_{\mathrm{x}}$ production rates in the Nashville urban plume, J. Geophys. Res., 107(D12), 4146, doi:10.1029/2001JD000932, 2002.

Treves, K. and Rudich, Y.: The Atmospheric Fate of $\mathrm{C}_{3}-\mathrm{C}_{6} \mathrm{Hy}-$ droxyalkyl Nitrates, J. Phys. Chem. A., 107, 7809-7817, 2003.

Turnipseed, A. A., Huey, L. G., Nemitz, E., Stickel, R., Higgs, J., Tanner, D. J., Slusher, D. L., Sparks, J. P., Flocke, F., and Guenther, A.: Eddy covariance fluxes of peroxyacetyl nitrates (PANs) and $\mathrm{NO}_{\mathrm{y}}$ to a coniferous forest, J. Geophys. Res., 111, D09304, doi:10:1029/2005JD006631, 2006.

Vaughan, S., Canosa-Mas, C., Pfrang, C., Shallcross, D., Watson, L., and Wayne, R.: Kinetic studies of reactions of the nitrate radical $\left(\mathrm{NO}_{3}\right)$ with peroxy radicals $\left(\mathrm{RO}_{2}\right)$ : an indirect source of OH at night?, Phys. Chem. Chem. Phys., 8, 3749-3760, 2006.

von Kuhlmann, R., Lawrence, M. G., Poschl, U., and Crutzen, P. J.: Sensitivities in global scale modeling of isoprene, Atmos. Chem. Phys., 4, 1-17, 2004,

http://www.atmos-chem-phys.net/4/1/2004/.

Wegener, R., Brauers, T., Koppmann, R., Bares, S. R., Roher, F., Tillmann, R., Wahner, A., Hansel, A., and Wisthaler, A.: Simulation chamber investigation of the reactions of ozone with short-chained alkenes, J. Geophys. Res., 112, D13301, doi: 10.1029/2006JD007531, 2007.

Wille, U., Becker, E., Schindler, R. N., Lancer, I. T., Poulet, G., and Le Bras, G.: A Discharge Flow Mass-Spectrometric Study of the Reaction Between the $\mathrm{NO}_{3}$ Radical and Isoprene, J. Atmos. Chem, 13, 183-193, 1991.

Wolfe, G. M., Thornton, J. A., Yatavelli, R. L. N., McKay, M., Goldstein, A. H., LaFranchi, B., Min, K.-E., and Cohen, R. C.: Eddy covariance fluxes of acyl peroxy nitrates (PAN, PPN and MPAN) above a Ponderosa pine forest, Atmos. Chem. Phys., 9, 615-634, 2009, 
http://www.atmos-chem-phys.net/9/615/2009/.

Wu, S., Mickley, L. J., Jacob, D. J., Logan, J. A., Yantosca, R. M., and Rind, D.: Why are there large differences between models in global budgets of tropospheric ozone?, J. Geophys. Res., 112, D05302, doi:10.1027/2006JD007801, 2007.
Zhang, Y., Huang, J. P., Henze, D. K., and Seinfeld, J. H.: Role of isoprene in secondary organic aerosol formation on a regional scale, J. Geophys. Res., 112, D20207, doi:10.1029/ 2007JD008675, 2007. 